Chapman University

Chapman University Digital Commons

$11-2-2020$

The Dark Side of Executive Compensation Duration: Evidence from Mergers and Acquisitions

Zhi Li

Qiyuan Peng

Follow this and additional works at: https://digitalcommons.chapman.edu/business_articles

Part of the Business Administration, Management, and Operations Commons, Organizational Behavior and Theory Commons, Other Business Commons, and the Strategic Management Policy Commons 


\section{The Dark Side of Executive Compensation Duration: Evidence from Mergers and Acquisitions}

\section{Comments}

This is a pre-copy-editing, author-produced PDF of an article accepted for publication in Journal of Financial and Quantitative Analysis, volume 56, issue 8, in 2021 following peer review. The definitive publisher-authenticated version is available online at https://doi.org/10.1017/S0022109020000812 .

\section{Copyright}

The authors 


\title{
The Dark Side of Executive Compensation Duration: Evidence from Mergers and Acquisitions
}

\author{
Zhi Li, Qiyuan Peng*
}

\footnotetext{
${ }^{*}$ Li, zli@chapman.edu, Chapman University Argyros School of Business \& Economics; Peng, qpeng1@udayton.edu, University of Dayton School of Business Administration. We thank the editor, an anonymous reviewer, Carl Chen, Ted Fee, Gus De Franco, Oleg Gredil, Candace Jens, David Mauer, Gans Narayanamoorthy, Ryan Peters, Sheri Tice, Adam Welker, Ting Zhang, Ruizhong Zhang and seminar participants at Tulane University, the 2017 Midwest Finance Association Conference, the 2019 California Corporate Finance Conference, and the 2019 Financial Management Association Conference for valuable comments. The authors assume responsibility for any remaining errors.
} 


\begin{abstract}
We find that contrary to popular belief, CEOs with long compensation duration do not make better longterm investment decisions. Using a comprehensive pay duration measure, we find that acquisitions conducted by CEOs with long compensation duration receive more negative announcement returns, and experience significantly worse post-acquisition abnormal operating and stock performance, compared with deals conducted by CEOs with short compensation duration. The negative correlation between compensation duration and M\&A performance is driven by long-term time-vesting plans, not by performance-vesting plans. The results suggest that extending CEO pay horizon without implementing performance requirements is insufficient to improve managerial long-term investment decisions.
\end{abstract}




\section{Introduction}

Over the past decade, U.S. public firms have faced increasing criticism about executives' focus on short-term firm performance at the expense of long-term shareholder value. ${ }^{1}$ Many practitioners and researchers argue that compensation design is partly to blame for short-termism, as executive pay is not sufficiently tied to long-term firm value. As a remedy, they suggest granting CEOs long-duration pay in order to extend the CEOs' investment horizon and improve their long-term invtestment decisions (e.g. Bebchuk and Fried (2010), Bhagat and Romano (2009), Pozen (2014), Edmans and Gabaix, (2016), among others). Although this idea makes sense intuitively, it is not backed by empirical evidence in the literature. And given the complexity of executive compensation contracts, a focus on one dimension of compensation design could easily have a limited or unintended effect on managerial behavior.

Several recent studies suggest that short compensation duration is associated with executive shorttermism. Using different methods to estimate pay duration based on salary, bonus, and equity-based grants, Chi, Gupta, and Johnson (2019) and Gopalan, Milbourn, Song, and Thakor (2014) find that CEOs with short pay duration are more likely to engage in earnings management. Using the amount of soon-to-vest equity grants as a proxy for executive pay horizon, Edmans, Fang, and Lewellen (2017) and Edmans, Fang, and Huang (2018) show that vesting equity is positively correlated with lower investment growth, share repurchases, and M\&A goodwill impairment. Nonetheless, the literature does not clarify whether longduration pay actually makes better long-term investment decisions. This gap in the literature is especially noticeable, given that the advocacy for extending compensation duration is based on such a premise.

In this paper, we attempt to fill this gap by investigating the relation between CEO compensation duration and subsequent merger and acquisition (M\&A) decisions. We focus on M\&A events for several reasons. First, M\&A decisions are among the most significant long-term investment decisions that CEOs make and can create or destroy significant shareholder value (Moeller, Schlingemann, and Stulz (2004)). Second, M\&A deals can greatly increase firm complexity and information asymmetry between managers

\footnotetext{
${ }^{1}$ For example, in Feb. 2016, the chief executive officer of BlackRock, Larry Fink, sent a well-publicized open letter that urges corporate executives to resist "the powerful forces of short-termism" and to "invest in long-term growth." (http://www.businessinsider.com/blackrock-ceo-larry-fink-letter-to-sp-500-ceos-2016-2)
} 
and shareholders, so CEOs could use these deals as opportunities for personal gain at the expense of shareholders (Grinstein and Hribar (2004), Harford and Li (2007)). Lastly, unlike internal investment decisions (such as those involving $R \& D$ and capital expenditures), M\&As have clear event dates and large value impacts that are measurable over multi-year periods. For these reasons, we believe that M\&A events provide a unique opportunity to examine the relation between CEO pay duration and the quality of longterm investments. If long compensation horizons indeed improve long-term investment decisions, we expect to find a positive correlation between the CEO pay horizon and subsequent M\&A performance.

Using U.S. public firms with detailed compensation data from 1998 to 2013, we construct a comprehensive measure of CEO compensation duration as the value-weighted average of the duration of short-term and long-term pay components within each CEO's annual compensation package. Unlike earlier papers on pay duration, which focus on salary, bonus, and equity-based pay (Chi et al. (2019), Gopalan et al. (2014)), we also incorporate non-equity-based performance incentives in our compensation duration estimation. Recent studies show that U.S. public firms increasingly rely on non-equity long-term performance-vesting pay to incentivize executives (Angelis and Grinstein (2015), Li and Wang (2016)). Our study is the first to incorporate all performance-vesting long-term plans in a CEO's annual compensation package to construct a more comprehensive pay horizon measure.

We identify 1,222 significant M\&A events completed from 1999 to 2013. Within our sample, the average deal size is $17 \%$ of the acquiring firm's market value of total assets, confirming the economic significance of these M\&A decisions. We find that CEO compensation duration is positively associated with a firm's propensity to conduct large acquisitions in the next year. However, the stock market reacts more negatively towards M\&As conducted by acquiring CEOs with long (above median) pay duration than those with short (below median) pay duration acquiring CEOs. After controlling for CEO characteristics, various deal and firm characteristics, and industry and year fixed effects, the significant negative correlation between CEO pay duration and market reaction persists. In contrast, there is no significant difference in target firm stock price reaction to deals conducted by acquirers with above or below median CEO pay duration. Nor do we find evidence that acquiring CEOs with long compensation duration pay higher acquisition premiums than their counterparts. Thus, the differences in the market's initial reaction towards 
acquirers is more likely driven by concerns over the quality of the deal than by concerns over the wealth transfer from acquirers to target firms.

It is possible that the market cannot fully understand the long-term value impact of M\&As at the time that the M\&As are announced, and that CEOs with long compensation duration are more willing to undertake unpopular acquisitions that will create shareholder value in the long run. Thus, the documented initial market reaction only reflects information asymmetry between managers and outside investors. To evaluate the quality of M\&As over the long term, we examine the post-M\&A operating and stock performance of the combined firms.

We find a strong negative relation between acquiring CEO pay duration and subsequent M\&A performance. Using a difference-in-differences approach, we find that firms with above-median pre-M\&A CEO pay duration experience significant deterioration in post-M\&A long-run ROA, compared with characteristic-matched peer firms. Meanwhile, acquisitions conducted by CEOs with below-median pay duration have changes in ROA that are comparable to those of characteristic-matched peers over the three years after deal completion. We further examine post-M\&A abnormal stock performance by estimating the combined firms' buy and hold abnormal returns (BHARs) benchmarked against matched peers. We find that stocks of acquirers with above-median CEO pay duration significantly underperform after deal completion, with median post-M\&A three-year BHAR of -14.57\%. In contrast, when acquiring CEOs have below-median pay duration, the combined firms' post-M\&A three-year BHAR is insignificant at $-3.82 \%$. The strong negative relation between pre-M\&A CEO pay duration and post-M\&A ROA and abnormal stock returns persist in a multivariate regression setting after controlling for the level of CEO overconfidence; firm, CEO, and deal characteristics; and year and industry fixed effects. Overall, the finding contradicts the idea that CEOs with long pay duration are more likely to conduct M\&As that create long-term synergy.

We conduct several tests to ensure the robustness of our findings. First, M\&A announcements and post-merger performances are only observed within firms that choose to conduct M\&As. To address potential self-selection bias, we estimate a two-stage Heckman model (Heckman (1979)) to control for 
firms' M\&A propensity and find similar results. Second, we estimate the duration of a CEO's entire portfolio holding ("portfolio duration") as an alternative measure of executive pay horizon. The results remain robust using the alternative duration measure. Third, we exclude CEOs approaching retirement age, as their investment horizon is inherently shorter, and our results remain unchanged.

We further undertake tests to ease concerns about potential endogeneity. We first employ a 2SLS/IV model to address the concern that hidden factors or omitted variables might influence both executive compensation design and M\&A decisions. We use median CEO pay duration from non-industryclustered firms within the same Metropolitan Statistical Areas (MSA) as our instrument. The literature has shown that firms clustered around the same metropolitan area tend to share similar CEO compensation design (Francis, Hasan, John, and Waisman (2016)). Under the 2SLS/IV model, we confirm the negative and significant relation between CEO pay duration and post-M\&A performance. Next, we employ the propensity score matching (PSM) method to further address the concern that the initial regression models might not control for non-linear differences between the long and short CEO compensation duration groups. We find that all results remain unchanged using a PSM matched sample.

Taken together, we find robust evidence that CEO pay duration is associated with significantly inferior post-M\&A performance. At the minimum, our findings cast doubt on the popular belief that longduration compensation contracts incentivize CEOs to make better long-term investment decisions. Given the complex nature of executive incentive contract, we next explore potential underlying factors that could influence the negative relation between CEO compensation duration and M\&A performance.

We first examine if a firm's governance attributes could affect the relation between pay duration and M\&A quality. We find that the negative relation between the acquirer's CEO pay duration and postM\&A performance remains significant after controlling for various governance characteristics (e.g., CEO tenure, duality, co-opted board). In addition, the coefficients on the interaction terms between CEO pay duration and these governance characteristics are insignificant. These results suggest that a firm's governance characteristics do not contribute to, and cannot alleviate, the negative correlation between CEO pay duration and subsequent M\&A performance. 
We next examine whether the underlying form of executive pay contributes to the relation between compensation duration and M\&A performance. Executive pay duration is derived from both time-vesting and performance-vesting long-term incentive plans. Earlier literature has questioned that time-vesting plans do not provide sufficient incentives as the payment is contingent only on the passage of time (e.g., Murphy (1999), Bebchuk and Fried (2009), Jensen, Murphy and Wruck (2004), and Kay and Putten (2007)). As a result, we expect that CEOs with time-vesting long-term plans would care less about the future value impact of M\&As than would CEOs with performance-vesting long-term plans. To test this conjecture, we measure pay duration of time-vesting plans and performance-vesting plans separately. Within the sample of firm years that grant time-vesting long-term plans to CEOs, the average plan duration is 2.56 years. The average duration of performance-vesting long-term plans is 2.72 years for firm years with such grants.

We find that the documented negative relation between the acquirer's CEO pay duration and subsequent M\&A quality is driven by time-vesting incentive pay alone. Only the duration from time-vesting pay is significantly negatively correlated with M\&A announcement return and post-M\&A performance. In contrast, duration of performance-vesting incentive pay is not associated with inferior M\&A deal quality. The results highlight the complexity of executive incentive design: pay duration is deeply intertwined with underlying contract design and should not be treated uniformly. Extending the CEO pay horizon without implementing performance requirements is associated with worse long-term investment outcomes.

This paper makes four contributions to the literature. First, to our knowledge, this is the first paper that directly evaluates the relation between CEO pay duration and the quality of managerial long-term investment decisions. A growing strand of literature examines the relations between executive horizon incentives and subsequent corporate decisions, as measured through earnings quality, disclosure of bad earnings forecasts, and executive retention (Chi et al. (2019), Gopalan et al. (2014), Cheng, Cho, and Kim (2014), Gopalan, Huang, and Maharjan (2016)). Our paper complements these studies by providing a new set of evidence on major long-term investment decisions.

Second, our paper is the first to distinguish between time-vesting pay duration and performancevesting pay duration. Earlier studies on compensation duration do not differentiate duration derived from 
different types of incentive contracts. Our findings suggest that long duration pay with underlying performance contingencies has different implications, for long-term managerial decisions, than long-term pay without underlying performance contingencies. Thus, focusing on duration alone in compensation design could lead to biased conclusions.

Third, our findings lend a cautionary note to the current enthusiasm for long-duration executive pay. We find no evidence supporting the prevailing view that longer executive compensation durations facilitate better long-term investment decisions. Earlier studies show that managers' short-term forecasts are more accurate than their long-term ones (Hirst, Koonce, and Venkataraman (2008)). Barzuza and Tally (2019) suggest that executives may be subject to "long-term bias," in which they overestimate the success rate of their long-term investments due to the long project horizon and sporadic feedback over time. Because increasing level of difficulty for managers to predict and plan over longer time horizons, boards should carefully weigh the costs and benefits of short-term and long-term incentive pay. If a board wishes to use long-duration pay to encourage CEOs to pursue long-term investments with uncertain outcomes, our study suggests that it is important to add performance contingencies to long-duration grants in order to ensure the quality of investment decisions.

Lastly, the paper contributes to the strand of literature that studies the role of managerial incentives in M\&A decisions. This literature has documented that certain types of compensation incentives, such as equity-based pay and CEO inside debt holdings, could affect M\&A decisions and subsequent performance (Datta, Datta, and Raman (2001), Phan (2014)). Harford and Li (2007) question the effectiveness of preacquisition compensation incentives, as firms may issue new equity grants after acquisition to decouple CEO wealth from merger performance. Our empirical evidence shows that time-vesting, long-duration incentive pay is negatively correlated with M\&A quality. 


\section{Sample and Variable Construction}

\section{A. Constructing CEO Compensation Duration}

We obtain the data to construct compensation duration mainly from the ISS Incentive Lab dataset. This dataset provides detailed information on equity- and non-equity-based grants to CEOs, including award type, grant date, plan size, vesting schedule, and vesting period. ${ }^{2}$ Our duration estimation method largely follows that of Gopalan et al. (2014), measuring pay duration as the weighted average of the vesting periods of the different components of executive pay. Gopalan et al. (2014) estimates compensation duration based on three components: salary, bonus, and equity-based pay (restricted stocks and options). However, recent papers show that U.S. public firms have increasingly used non-equity performance plans over the past decade (Angelis and Grinstein (2015), Li and Wang (2016)). These plans consist of cashbased incentive pay contingent on firms achieving long-term performance goals. To construct a more comprehensive executive pay horizon measure, we therefore incorporate non-equity performance pay as a fourth compensation component. ${ }^{3}$ We estimate a CEO's compensation duration (COMPENSATION_DURATION) as the value-weighted average of the vesting period of each component in annual compensation contracts:

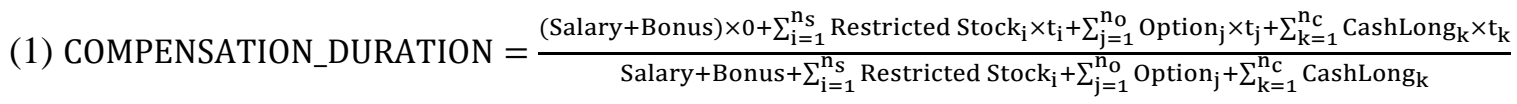

In equation (1), salary and bonus are dollar values of annual salary and bonus reported in summary compensation tables. They are considered to have zero duration by the end of the fiscal year. CEOs might receive multiple equity-based and non-equity-based grants within each year, with $n_{s}, n_{o}$, and $n_{k}$ representing the total number of restricted stocks, options, and long-term cash-based plans granted in fiscal year t, respectively. Restricted stock $\mathrm{k}_{\mathrm{i}}$ is the grant date fair value of the $\mathrm{i}^{\text {th }}$ stock grant with vesting period $\mathrm{t}_{\mathrm{i}}$ (in years)

\footnotetext{
${ }^{2}$ The ISS Incentive Lab database focuses on the largest 750 firms in terms of market capitalization each year. It covers around 2,000 US public companies in total from 1998 due to back-fill and forward-fill of data. The companies covered are from the S\&P500 and a significant portion of the S\&P400.

${ }^{3}$ Salary, bonus, equity-based grants, and non-equity grants compose the majority of executive pay package. However, we acknowledge that other components of executive contract that could affect managerial horizon are not incorporated in the pay duration measure - for example, managers' inside debt, retirement benefits, and clawback provisions, among others (e.g., Sundaram and Yermack (2007), Chan, Chen, and Chen (2013), Kalyta (2009)). The difficulty in incorporating these components is that there is no widely accepted method to quantify their value and duration.
} 
by the end of the year. Option ${ }_{j}$ is the Black-Scholes value of $j^{\text {th }}$ option grant with vesting period $t_{j}$ by the end of the year. ${ }^{4}$ CashLong ${ }_{k}$ is the grant date target value of non-equity long-term performance plans with corresponding vesting period $t_{k}$. Panel A of Table 1 reports summary statistics of CEO pay duration and compensation structure within our sample from 1998 to $2013 .^{5}$ The average CEO compensation duration is 1.51 years, with a median of 1.59 years. This is slightly longer than that reported in Gopalan et al. (2014) due to the inclusion of long-term non-equity grants. In untabulated tests, we conduct all main tests using the Gopalan et al. (2014) compensation duration measure as a robustness check. The results are generally consistent with those using our compensation duration measure.

[Insert Panel A and Pane B of Table 1 about here]

As robustness check, we estimate the duration of a CEO's entire portfolio holdings (PORTFOLIO_DURATION) as an alternative measure of pay horizon. ${ }^{6}$ The portfolio duration is estimated as the weighted average of the vesting periods of all unvested and vested equity grants. Vested non-equity grants are no longer part of a CEO's portfolio holding, as they are paid out in cash (or equivalent) to CEOs once vested.

(2) PORTFOLIO_DURAITON $=\frac{\sum_{i=1}^{n_{s}} \text { Unvested Equity Holding }{ }_{i} \times t_{i}+\sum_{k=1}^{n_{c}} \text { Unvested Nonequity Holding }_{k} \times t_{k}}{\sum_{i=1}^{n_{0}} \text { Unvested Equity Holding } i_{i}+\sum_{j=1}^{n_{0}} \text { Vested Equity Holding }{ }_{j}+\sum_{k=1}^{n_{c}} \text { Unvested Nonequity Holding }_{k}}$

In equation (2), each component is value weighted by the CEO's overall portfolio holding. The "Vested Equity Holding," is the value of all vested stocks and options that the CEO holds by the end of the fiscal year and is considered to have zero duration. 7 "Unvested Equity Holding." includes the value of all unvested restricted stocks and options with vesting period $t_{i}$ that the CEO holds by the end of the fiscal year. "Unvested non-equity holding $\mathrm{k}_{\mathrm{k}}$ " includes the value of all long-term non-equity plans with vesting period $t_{\mathrm{k}}$

\footnotetext{
${ }^{4}$ We estimate the Black-Scholes value for each option grant following Coles, Daniel, and Naveen (2006), with grant dates, exercise prices, and maturity dates of option grants reported in ISS Incentive Lab.

${ }^{5}$ All non-binary variables are winsorized at $1 \%$ and $99 \%$, and all dollar values are adjusted to constant 2006 dollars.

${ }^{6}$ Our baseline analysis focuses on "compensation duration" based on a CEO's annual pay as it reflects the board's latest intention in compensation design and is less affected by the CEO's personal decision to keep or unload vested equity grants. In addition, due to the limited data before 2006 on equity grants' vesting schedule, the estimation of CEO portfolio duration requires additional assumptions that could lead to higher measurement errors (Gopalan et al. (2014)).

${ }^{7}$ We estimate the Black-Scholes value for each option grant following Coles et al. (2006). Restricted stock value is estimated as number of shares multiplied by stock price per share at the end of fiscal year.
} 
that the CEO holds by the end of the fiscal year. ${ }^{8}$ Portfolio duration has an average (median) of $0.68(0.58)$ years. ${ }^{9}$

\section{[Insert Figure 1 about here]}

Next, we decompose compensation duration based on grant types. Option grants, the most widely used long-term compensation incentive for CEOs, are used in $70.57 \%$ of firm years. Within firm years that use option grants, the average (median) option duration is 2.46 (2.50) years. The next most widely used incentive, restricted stock, is granted in $58.19 \%$ of firm years, with an average (median) duration of 2.75 (3.00) years. Over the sample period, the use of option grants declines by one third (Figure 1); restricted stock replaces option grants as the biggest component of CEO pay duration in 2006 and remains so through the end of the sample period. Long-term non-equity plans are granted to CEOs in $10.1 \%$ of firm years on average, with the longest average plan duration of 2.91 years.

\section{B. Merger and Acquisition Sample}

We then identify all M\&As from the Security Data Company (SDC) US M\&A database with announcement dates between January 1, 1999, and December 31, 2013. To focus on significant M\&As that have detectable performance and value impacts on acquirers, we require the transaction value to be at least $\$ 1$ million and at least $1 \%$ of the acquirer's market capitalization, measured as the market value of total assets at the pre-M\&A announcement fiscal year end. Lastly, we require all M\&As to be completed and that the acquirers have valid CEO compensation data from the ISS Incentive Lab, related CEO information from Execucomp, non-missing firm variables from Compustat, and stock-related information from CRSP. Our final sample consists of 1,222 large M\&A transactions with a median deal size of \$687 million, which accounts for $17 \%$ of the acquirer's market capitalization on average.

[Insert Panel A and Panel B of Table 2 about here]

\footnotetext{
${ }^{8}$ Following Gopalan et al. (2014), we estimate the vesting periods of unvested equity grants using information from the outstanding equity table, which is required in proxy statements after 2006. Before 2006, firms were not required to report detailed vesting schedules of outstanding equity grants in proxy statements. We follow the method used in Chi et al. (2019) to estimate the vesting schedule of an outstanding equity grant if the information is missing.

${ }^{9}$ The CEO portfolio-holding duration is shorter than the compensation duration, as vested stocks and options that the CEO holds are considered to have zero duration.
} 
Table 2 presents descriptive statistics of the 1,222 completed M\&As from 1999 to 2013. The annual distribution of the sample, shown in Panel A, indicates that acquisitions are generally not clustered except for in the years 1999 and 2000 (during the dot-com bubble). The overall sample consists of 651 unique acquirers. Panel B of Table 2 reports deal characteristics. We split the M\&A sample into two groups based on median CEO compensation duration. The deal value of M\&As conducted by acquiring firms with long (above median) CEO pay duration is larger than that of M\&As conducted by firms with short (below median) CEO pay duration ( $\$ 733$ million vs. $\$ 570$ million, respectively). This is consistent with larger firms having longer CEO compensation duration than smaller firms (Gopalan et al. (2014)). The relative deal size as a percentage to acquirer's market size is similar between groups, with a median of $7 \%$. Further, acquirers with long CEO pay duration and acquirers with short CEO pay duration do not differ significantly in terms of M\&A payment method, hostile takeover, tender offers, or private target firms. Overall, the univariate comparison indicates that firms with long CEO pay duration and firms with short CEO pay duration engage in M\&As of similar characteristics.

\section{CEO Compensation Duration and Acquisition Propensity}

We conduct a preliminary analysis of whether CEO compensation duration is associated with M\&A propensity using the following probit regression setting: ${ }^{10}$

(3) $\operatorname{Pr}\left(\right.$ Acquisition $\left._{\mathrm{i}, \mathrm{t}}=1\right)=\Phi\left(\alpha+\beta_{1} \times\right.$ COMPENSATION_DURATION $\left._{\mathrm{i}, \mathrm{t}-1}+\mathbf{X}_{\mathbf{i}, \mathbf{t}-\mathbf{1}}^{\prime} \boldsymbol{\beta}+\varepsilon_{\mathrm{i}, \mathrm{t}-1}\right)$.

The dependent variable is a binary variable that equals one if a firm announces an acquisition in year $\mathrm{t}$. The independent variables, including CEO pay duration and control variables (X), are measured at the end of the fiscal year (t-1) prior to the M\&A announcement. Following the literature (Datta et al. (2001), Malmendier and Tate (2008); Phan (2014)), we include the following firm-level controls: size (logarithm of total assets), performance (ROA and prior year stock returns), growth opportunities (Firm's Q), risk (stock return volatility), industry concentration (Herfindahl Index), leverage, and age. Because the literature has shown that overconfident CEOs are more acquisitive (Malmendier and Tate (2008)), we further control

\footnotetext{
${ }^{10}$ In untabulated tests, we find similar results using the logit analysis.
} 
for CEO overconfidence, using an indicator variable that equals one if a CEO keeps option grants that are more than $100 \%$ in-the-money at the expiration year at least twice during her tenure within the sample period. We also include year and industry fixed effects based on the Fama-French 48 industry classifications.

\section{[Insert Table 3 about here]}

In Table 3, Column (1) reports the baseline regression results. The coefficient of CEO compensation duration is positive and significant at the $1 \%$ level, indicating that CEOs with longer pay duration are more likely to conduct M\&As in the next year. Column (2) shows confirming evidence using the alternative duration measure, CEO portfolio duration. We report the marginal effects at the sample mean from the estimated probit model in Columns (3) and (4). If the CEO compensation duration is extended by one year, the probability of the CEO conducting a large M\&A in the next year increases by $0.5 \%$; this represents a $6.2 \%$ increase from the sample acquisition probability of $8.12 \%$. The coefficients on control variables in the probit model are largely consistent with prior M\&A literature: they show that large firms and firms with strong past performance are more likely to conduct acquisitions in the next year, and that CEO overconfidence is positively correlated with future M\&A events. ${ }^{11}$

The evidence does not indicate a causal link between CEO pay duration and M\&A propensity. It is possible that CEOs with long-duration pay are more willing to take on long-term projects like M\&As, or, non-mutually exclusively, some firms grant long-duration contracts to CEOs in anticipation of future M\&A events. ${ }^{12}$ Regardless of the causal relation, our research question focuses on whether CEOs with long duration compensation contract would make better M\&A decisions than those with short duration pay.

\footnotetext{
${ }^{11}$ As a robustness check, we rerun the likelihood regression to isolate the effect of serial acquisitions by excluding acquisitions announced within one year after the deal completion date of the same acquirer. The untabulated results remain unchanged.

${ }^{12}$ We cannot exclude the possibility that at least some CEOs are granted long-duration pay when the firm is expected to conduct M\&As. Gopalan et al. (2014) find executive pay duration is positively related to long-term investments (R\&D spending and long-term assets). But the causal effect of executive pay duration on a firm's propensity to conduct long-term investments is also unclear.
} 


\section{Empirical Methodology and Main Results}

In this section, we study the relation between CEO compensation duration and subsequent M\&A performance. If CEOs with long pay duration are motivated to improve long-term shareholder value, we expect them to undertake high-quality M\&As.

\section{A. CEO Compensation Duration and M\&A Announcement Abnormal Returns}

We first test this hypothesis by studying stock market reaction to M\&A announcements. Following Brown and Warner (1985), we calculate cumulative abnormal returns (CARs) around the M\&A announcement date benchmarked against the Fama-French three-factor model. ${ }^{13}$

[Insert Panel A of Table 4 about here]

Panel A of Table 4 reports a univariate comparison of three-day CARs of acquiring firms and public target firms around M\&A announcement dates. Within the whole sample, the 1,157 acquirers have an average (median) three-day CAR of $-0.97 \%(-0.72 \%)$, significant at the $1 \%$ level. This is consistent with findings in earlier literature that large acquisitions usually draw skepticism from the market. We next sort the acquirers into two groups based on median CEO compensation duration before the M\&A announcement. The average (median) CARs for acquirers with above-median CEO pay duration is $-1.34 \%(-0.97 \%)$ and significant at $1 \%$. In contrast, acquirers with below-median CEO pay duration have significantly higher average (median) CARs: $-0.59 \%(-0.46 \%)$.

Various deal and firm characteristics could affect how the stock market reacts to M\&As. To further examine the relation between acquirer CEO compensation duration and the market's reaction to acquiring firms, we use the following multivariate regression.

(4) Acquirer's CAR $\mathrm{i}_{\mathrm{t}, \mathrm{t}}=\alpha+\beta_{1} \times$ COMPENSATION_DURATION $_{\mathrm{t}-1}+\mathbf{X}_{\mathbf{i}, \mathrm{t}-\mathbf{1}}^{\prime} \boldsymbol{\beta}+\varepsilon_{\mathrm{i}, \mathrm{t}-1}$.

The dependent variable is each acquirer's three-day CAR around the M\&A announcement date. Following the literature on market reactions to M\&A news (Datta et al. (2001), Moeller et al. (2004),

\footnotetext{
${ }^{13}$ We use 255 through 46 trading days before M\&A announcement date as estimation period. For each M\&A event, we require that the acquiring firm has at least 30 non-missing trading days during the estimation periods.
} 
Masulis et al. (2007), Phan (2014)), we control for acquirer characteristics, including size, performance, and investment opportunities. We also control for deal characteristics, including relative deal size, whether acquirer and target firms are in the same industry, and indicators for all-cash deal, tender offer, hostile takeover, and target public status. Other control variables are CEO-related: CEO overconfidence, age, stock ownership, and total compensations scaled by firm total assets. All independent variables are measured at the end of the fiscal year prior to the acquisition announcement date. All regressions include year and industry fixed effects.

[Insert Panel B of Table 4 about here]

The first two columns in Panel B of Table 4 show that the coefficients on CEO compensation duration and CEO portfolio duration are both negative (-0.565 and -0.881 , respectively) and significant. Conditional on constant control variables within the M\&A sample, a one standard deviation (0.874) increase in the acquirer's CEO compensation duration is associated with 49-basis point reduction in the acquirer's three-day announcement CARs. The coefficients on control variables are largely consistent with findings in the earlier literature. Acquirers with public targets experience significantly lower announcement abnormal returns than acquirers with private targets (Chang (1998)). Acquirer size and relative deal size are negatively but insignificantly related to acquirers' announcement abnormal returns.

Because we can only observe acquirers' announcement abnormal returns when firms conduct M\&As, the regression model (4) is subject to potential self-selection bias. We therefore use the Heckman $(1976,1979)$ two-stage selection model to control for firms' propensity to conduct M\&As. In the first stage, we use the same model as in Equation (3) to estimate a firm's probability to conduct an M\&A in the next year. We include two instrument variables that are correlated with M\&A propensity but are unlikely to be correlated with merger outcomes. ${ }^{14}$ The first is pre-M\&A long-run cash volatility (CASH_VOLATILITY), measured as the standard deviation of a firm's demeaned cash balance over the five-year period before M\&A announcement. Bharath and $\mathrm{Wu}(2005)$ show that there is strong run-up in long-term volatility over the years prior to M\&As, indicating that acquisitions are firms' responses to industry shocks. Pre-M\&A

\footnotetext{
${ }^{14}$ However, the exclusion restriction is not critical for Heckman model identification ( $\mathrm{Li}$ and Prabhala (2006), Golubov, Petmezas, and Travlos (2012)).
} 
long-run cash volatility is not expected to be correlated with M\&A announcement returns, as daily abnormal stock returns in short-term event studies are unlikely to be related to firm-level variables (Brown and Warner, 1985). The second variable is pre-M\&A interim industry-level uncertainty. Bhagwat, Dam, and Harford (2016) show that exposure to interim market volatility reduces M\&A activities, as potential acquirers and targets are concerned that market conditions may deteriorate between the deal's announcement day and completion day. Further, they show that higher industry-level interim market risk is negatively associated with industrywide M\&A activity. Motivated by their findings, we measure preM\&A industry-level interim market risk as median annual beta of a firm's industry peers (INTERIM_INDUSTRY_UNCERTAINTY). As the variable is derived from industry peers, it should not be directly related to a firm's specific future M\&A performance.

Columns (1) and (2) of Table 3 show the Heckman first-stage results with compensation duration and portfolio duration, respectively. The coefficients on long-run cash volatility and median industry peers' beta confirm that both variables are strongly correlated with future M\&A propensity. The second-stage model includes the same independent variables from equation (4), plus the Inverse Mills Ratio estimated from the first stage of the Heckman model. Columns (3) and (4) of Panel B Table 4 report the second-stage results. The coefficients on acquirer CEO pay duration and portfolio duration remain negative $(-0.722$, 1.102) and significant at the 5\% level. In addition, the coefficients on Inverse Mills Ratio are insignificant, suggesting that the self-selection bias is not substantial in the original multi-regression model on acquirer abnormal announcement returns.

The negative market reaction towards acquirers with long pay duration CEOs may be driven by a higher merger premium paid for target firms. If this is the case, then the market should react more positively towards the target firms when the acquirer CEOs have long compensation duration. The bottom half of Panel A Table 4 reports three-day CARs around announcement day for 694 public target firms. With long CEO pay duration acquirers, target firms experience average (median) three-day CARs of $22.87 \%$ (20.04\%). With short CEO pay duration acquirers, target firms have similar average (median) CARs of $25.46 \%$ (21.05\%). The difference in CARs between the two groups is not statistically significant. Thus, the results 
do not support the idea that the negative market reaction towards acquirers with long CEO pay duration is due to greater wealth transfer from acquirer shareholders to target shareholders.

\section{[Insert Panel C of Table 4 about here]}

We then directly examine the relation between CEO compensation duration and the merger premium paid for target firms in a multivariate regression setting. ${ }^{15}$ Following the literature (Moeller, et al. (2004), Fu, Lin and Officer (2013)), we control for acquirer and target firm size, investment opportunities, and performance (i.e., ROA, pre-M\&A year stock return); deal characteristics (i.e., deal size, payment method, diversifying merger, hostile takeover, tender offers, or private target firms); and the acquirer CEO's pay level and overconfidence. The results are presented in Panel C, Table 4. Columns (1) and (2) show that the coefficients of CEO pay duration and portfolio duration are both insignificant, confirming that acquirers with long CEO pay duration do not pay higher premiums for target firms. We find confirmatory evidence of this using the two-stage Heckman selection model (Columns (3) and (4)), as the coefficients on acquirer CEO pay duration and portfolio duration are all insignificant. Overall, the results suggest that concerns about overpayment for target firms are unlikely to drive the more negative market reaction towards acquirers with long CEO pay duration. The negative reaction is more likely driven by concerns over deal quality.

\section{B. CEO Compensation Duration and Long-term Abnormal Operating Performance}

CEOs with long compensation duration may have strong incentives to undertake unpopular acquisitions that will create synergies in the long run. It is possible that, at the time of the deal announcement, the market cannot fully understand the long-term value impact of such acquisitions. Therefore, the negative initial market reaction documented above might only reflect information asymmetry between CEOs and outside investors. To further evaluate the quality of CEOs' acquisition decisions, we examine the relation between acquirer CEO pay duration and post-M\&A long-run operating performance of the combined firms.

\footnotetext{
${ }^{15}$ We define the premium as the value of the deal size divided by the market value of the target at least 40 days prior to and at most 50 days prior to the announcement day.
} 
Following the literature, we first measure post-M\&A long-run abnormal operating performance using a difference-in-differences approach. We calculate the combined firm's post-M\&A change in industry-adjusted return on total assets (ROA) from pre-M\&A year t-1 to one year $(t+1)$, two years $(t+2)$, and three years ( $t+3)$ after M\&A completion (Fu et al. (2013)). In the pre-M\&A year $t-1$, the combined firm's ROA is calculated as the weighted average of ROA of the acquirer and the target, weighted by book value of total assets of the two firms at the beginning of the pre-M\&A year. We then adjust the ROA of each combined firm with the industry annual median ROA using the Fama-French 48 industry classification. In the pre-M\&A year, the industry median ROA is the weighted average of the acquirer's and target's industry median ROA, weighted by the two firms' book value of total assets (Healy, Palepu, and Ruback (1992)). To further control for ROA trends related to firm characteristics, we match each acquirer with a non-M\&A peer firm (Barber and Lyon, 1996). The matched firm must remain public within the five-year window from year $\mathrm{t}-1$ to year $\mathrm{t}+3$; have not been involved in M\&A over the past three years; have a market value within the range of $90 \%$ to $110 \%$ of that of the combined firm's market value; and have the closest ROA to that of the acquiring firm in the pre-M\&A year. The long-run post-M\&A abnormal operating performance is estimated as the difference between change in industry-adjusted ROA of the combined firm from the pre-M\&A year to the post-M\&A year(s) and change in industry-adjusted ROA of the characteristic-matched firm over the same time period.

\section{[Insert Panel A of Table 5 about here]}

Panel A of Table 5 presents the difference-in-differences result. The analysis requires that the acquirer has a public peer that matches it in pre-M\&A firm characteristics, and that the target be a public firm with observable ROAs in pre-M\&A year t-1. Following the literature (Li, Qiu, and Shen (2018)), we further require that acquirers must not complete any confounding significant M\&A within one, two or three years after deal completion to exclude the effect of overlapping measurement windows when estimating long-run post-M\&A performance over the respective time period. ${ }^{16}$ We end up with 366 combined M\&A firms with matched peers having valid ROAs from the pre- to the post-M\&A completion year. ${ }^{17}$ For

\footnotetext{
${ }^{16}$ Our results remain robust if we do not impose this restriction.

17 The number of observations drops to 304 (259) over the next two (three) years after M\&A completion year.
} 
acquirers with long compensation duration CEOs, the combined firms' abnormal change in industryadjusted ROA after deal completion is significantly negative, indicating that the merged companies significantly underperform their characteristic matched peers. The median abnormal change in adjusted ROA ranges from $-1.99 \%$ (significant at $1 \%$ ) one year after the M\&A to $-2.40 \%$ (significant at $1 \%$ ) three years after the M\&A. In contrast, when acquirers have short CEO pay duration, the combined firms do not underperform over the long run - their post-M\&A change in industry-adjusted ROA is comparable to the change in adjusted ROA of matched peers. The median difference in change in adjusted ROA is insignificant at $1.16 \%$ three years after the M\&A. The last two columns show the difference in abnormal changes in combined firms' ROA between acquiring firms with long and short pay duration CEOs. The results confirm that acquirers with long compensation duration CEOs experience significantly worse changes in long-run abnormal ROA after M\&As.

We further examine the relation between acquiring firm's CEO compensation duration and postM\&A long-term operating performance using the following multivariate regression model.

(5) Change in $\mathrm{ROA}_{\mathrm{i}, \mathrm{t}-1 \text { to } \mathrm{t}+3}=\alpha+\beta_{1} \times$ COMPENSATION_DURATION $_{\mathrm{i}, \mathrm{t}-1}+\mathbf{X}_{\mathrm{i}, \mathrm{t}-\mathbf{1}}^{\prime} \boldsymbol{\beta}+\varepsilon_{\mathrm{i}, \mathrm{t}-1}$.

The dependent variable is the changes in industry-adjusted ROA of the combined firms from three years after M\&A completion ( $\mathrm{t}+3)$ to the pre-M\&A completion year ( $\mathrm{t}-1)$. We control for $\mathrm{M} \& \mathrm{~A}$ deal characteristics, acquirer firm characteristics, pre-M\&A performance, and acquirer CEO overconfidence. ${ }^{18}$

\section{[Insert Panel B of Table 5 about here]}

Panel B of Table 5 reports the regression results. In Column (1), the coefficient on CEO compensation duration is negative (-1.628) and significant at the $1 \%$ level, confirming that acquirer CEO pay duration is associated with significantly lower abnormal long-term operating performance after M\&A completion. Column (2) shows confirming evidence that the coefficient on CEO portfolio duration is negative (-2.128) and significant at the $1 \%$ level. Columns (3) and (4) present similar results from Heckman model to control for the self-selection concern. Overall, the results presented in Table 5 show that CEOs

\footnotetext{
${ }^{18}$ For the regression analysis, we require that the target firms be public, and that the combined firms have valid ROA and other control variables in pre- and post-M\&A years. We end up with 352 combined M\&A firms with valid data.
} 
with long pay duration conduct M\&As that significantly underperform their matched peers in long-run operating performance, while CEOs with short pay duration conduct M\&As that do not underperform their matched peers.

\section{CEO Compensation Duration and Long-Term Abnormal Stock Performance}

CEOs with long compensation duration may be more likely to focus on improving firms' long-run stock performance after M\&A, as stock performance is directly tied to shareholder wealth. In this section, we examine the relation between acquirer CEO pay duration and post-M\&A long-run stock performance. We follow Barber and Lyon (1997) to calculate the post-M\&A buy-and-hold abnormal returns (BHARs) as the difference between the buy-and-hold returns of the acquirers over one to three years after M\&A completion and the buy-and-hold returns of matched benchmark firms over the same period.

For each acquiring firm, we select a matched benchmark firm that has not been involved in any M\&A over the past three years, has market value within $70 \%-130 \%$ of the acquirer's market value measured 11 days prior to M\&A announcement date, and has the closest market-to-book ratio to that of the acquirer at the end of pre-M\&A fiscal year. We further require that the acquirer does not conduct confounding significant M\&A within one, two, or three years after deal completion when estimating postM\&A BHARs over the respective windows. We end up with 986 acquirers with matched peers that have at least one year of valid stock returns after deal completion. The number of observations drops to 853 and 759 acquirers two and three years after M\&A completion, respectively.

\section{[Insert Panel A of Table 6 about here]}

Panel A of Table 6 presents the mean and median post-M\&A BHARs of the acquiring firms and of the above- and below-median subgroups of acquiring firms. The results suggest that the negative postM\&A long-run abnormal stock performance is mainly driven by acquirers with long pay duration CEOs. Columns (4) to (5) show that acquirers with long CEO pay duration significantly underperform their matched peers after M\&A. The median post-M\&A 3-year BHAR is $-14.57 \%$, significant at the $1 \%$ level. In contrast, the BHARs of acquirers with short CEO pay duration are indifferent from zero over one to three years after the M\&A, indicating that the combined firms do not underperform their matched peers. The last 
two columns report the difference in long-run BHARs between the two duration groups. The BHARs of acquiring firms with long pay duration CEOs is significantly lower than that of acquirers with short pay duration CEOs over one to three years after M\&A deal completion.

Following the literature, we further investigate the relation between acquirer CEO pay duration and post-M\&A BHARs using a multivariate regression model:

(6) BHAR $_{\mathrm{i}, \mathrm{t}}=\alpha+\beta_{1} \times$ COMPENSATION_DURATION $\mathrm{i}_{\mathrm{i}, \mathrm{t}-1}+\mathbf{X}_{\mathrm{i}, \mathrm{t}-\mathbf{1}}^{\prime} \boldsymbol{\beta}+\varepsilon_{\mathrm{i}, \mathrm{t}-1}$

The dependent variables are the acquirers' long-term BHARs over 24 and 36 months after M\&A announcement. The BHARs have been adjusted for firm size and Q. Following earlier studies on postM\&A stock performance (Datta et al. (2001), Chen, Harford and Li (2007), Phan (2014)), we further control for sales, performance, leverage, cash flow, stock volatility, firm age, and deal and CEO characteristics, measured at the end of the fiscal year prior to the deal announcement. We also include year and industry fixed effects.

\section{[Insert Panel B of Table 6 about here]}

Panel B of Table 6 presents the multivariate regression results. Column (1) shows that acquirer CEO pay duration is associated with significantly lower 24-month post-M\&A abnormal stock returns. In terms of economic significance, a one standard deviation increase in pre-M\&A acquirer CEO compensation duration is correlated with a $5.17 \%$ decrease in post-M\&A BHAR within a 24-month window. Under the Heckman selection model, we confirm the significantly negative relation between CEO pay duration and subsequent post-M\&A BHARs. Columns (5) and (7) confirm that acquirer CEO pay duration is negatively associated with 36-month post M\&A BHARs. When we use portfolio duration as an alternative measure of CEO pay horizon, we find similar, albeit less significant, results. Overall, the evidence shows that acquirers with long duration pay CEOs experience significant deterioration in both operation and stock performance after M\&A completion, while acquirers with short duration pay CEOs do not underperform. 


\section{Addressing Endogeneity Concerns}

The evidence above consistently shows a negative relation between acquirer CEO pay duration and post-M\&A operating and stock performance. However, to confirm the validity of the results, it is important to mitigate potential endogeneity concerns that omitted variables or hidden factors jointly determine the design of CEO compensation contracts and the quality of subsequent M\&A deals. In this section, we undertake additional empirical analyses to address such concerns.

\section{2SLS/IV Estimation}

We first use a 2SLS/IV model to address endogeneity concerns related to unobserved time-varying omitted variables. We use the median CEO compensation duration from non-industry-clustered peer firms within the same MSA code (MSA_PEER_COMPENSATION_DURATION) as instrument variables (IV). Past literature has shown that a firm's executive compensation design is highly correlated with that of local peers, as compensation packages of local firms reflect opportunities in the local labor market (Francis et al. (2016)). Certain industries may cluster around the same MSA area, influencing both local compensation design and M\&A decisions. Thus, we exclude firm years from the same industry cluster when estimating the IV. ${ }^{19}$ Consequently, the IV should be affected by compensation practices in the local labor market but not by geographically clustered industries in the local area. Further, local peers' compensation practices should not be directly related to a firm's future M\&A performance. Thus, we expect our instrument to meet both the relevance and exclusion restrictions. Testing the relevance and strength of the IV, the Kleibergen-Papp rk LM statistic rejects the null hypothesis that the IV is irrelevant to the endogenous variable, CEO pay duration. In addition, the first-stage F-statistic is above 10, and the Cragg-Donald Wald F-statistic is higher than the Stock-Yogo weak ID test critical values. Overall, test results reject the null hypothesis that our IV is weak.

[Insert Table 7 about here]

\footnotetext{
${ }^{19}$ Following Almazan, De Motta, Titman, and Uysal (2010), we define a firm year as part of an industry cluster if there are 10 or more firms from the same 3-digit SIC industry within an MSA area or if the aggregate market value of firms in the same industry is at least $3 \%$ of the total market value. We thank the referee for suggesting the potential impact of industry cluster within an MSA area.
} 
Table 7 presents the 2SLS/IV regression results on acquirers' M\&A announcement return (i.e., three-day CAR), post-M\&A operating performance (i.e., change in industry-adjusted abnormal ROA), and post-M\&A stock performance (i.e., 24-month BHARs). To preserve space, we only present coefficients on the IV in the first stage and coefficients on the predicted CEO pay duration in the second stage. The regression control variables are the same as in Panel B of Tables 4, 5, and 6. The first-stage results, presented in Columns (1), (3), and (5), show that the non-industry-clustered MSA peer firm median compensation duration is significantly and positively related to the CEO pay duration at the firm level. The second-stage results, presented in Columns (2), (4), and (6) confirm that acquiring firms with long CEO pay duration experience significantly lower abnormal returns around M\&A announcement dates, lower changes in abnormal ROA after M\&A completion, and lower post-M\&A long-run abnormal stock returns.

\section{Propensity Score Matching Method}

Another concern is that firms that grant CEOs long duration pay are inherently different from firms that grant short duration compensation. The current control variables and regression model may fail to control for omitted variables related to the nonlinear form of firm characteristics (Rosenbaum and Rubin (1983), Dehejia and Wahba (2002), Hirano, Imbens, and Ridder (2003)). To address this concern, we reexamine the main tests using a propensity score matched sample.

We define the treated firms as acquirers with above-median CEO compensation duration in year $\mathrm{t}$, and the control firms as acquirers with below-median CEO compensation duration in year t. We first use a probit model to estimate the propensity score of a firm with long CEO pay duration in year t. Following Gopalan et al. (2014), we control for firm size, growth opportunities, R\&D intensity, firm risk, and stock performance in year t. ${ }^{20}$ We also include year and industry fixed effects using the Fama-French 48 industry classification. We then match each treated firm to the control firm with the closest propensity score without replacement. To ensure the quality of the matching procedure, we exclude firms that do not have propensity score matches within a caliper of $1.5 \%$. We end up with 788 acquirers in total in the treated plus control

\footnotetext{
${ }^{20}$ Gopalan et al. (2014) show that CEO pay duration is longer in firms with larger size, more growth opportunities, more long-term assets, greater R\&D intensity, lower firm risk, and better recent stock performance.
} 
groups. Lack of data availability for M\&A announcement date abnormal return, long-run post-M\&A abnormal returns, and regression control variables further reduces the sample size. For tests on post-M\&A abnormal change in ROA, the sample is restricted to acquirers of public targets that have valid pre- and post-M\&A accounting information. For tests on post-M\&A BHARs, the sample requires valid post-M\&A stock information. We further require that acquirers must not complete any confounding significant M\&A within the respective measurement windows after deal completion.

[Insert Panel A and Panel B of Table 8 about here]

To evaluate the robustness of the matching process, we compare firm characteristics of treated and matched control firms. Panel A of Table 8 shows that there is no significant difference in mean firm characteristics between the treated and control groups. Panel B reports performance regression results using propensity score matched control firms. The regression specifications are the same as in Tables 4, 5, and 6 . To conserve space, we only report the coefficients on CEO compensation duration. The results confirm all our earlier findings. Overall, endogeneity concerns do not change our main finding that CEO pay duration is associated with inferior M\&A performance.

\section{Further Robustness Test}

Earlier research suggests that the short career horizons of CEOs approaching retirement age may affect their investment decisions (Dechow and Sloan (1991)). To ensure that our results are not influenced by retiring CEOs, we exclude CEOs who are over 60 from the sample. In untabulated tests, we find that all results remain unchanged within this sample.

\section{What Influences the Relation Between CEO Pay Duration and M\&A Quality?}

The persistent negative relation between CEO pay duration and future M\&A performance is both unexpected and puzzling. At a minimum, the evidence does not support the popular belief that CEOs with long-duration pay make better long-term investment decisions. Given the complex nature of executive incentive design, we next explore whether certain firm or contract attributes influence the negative relation we have observed. 


\section{A. Governance Characteristics and the Relation Between CEO Pay Duration and M\&A Quality}

We first examine whether a firm's governance attributes explain the relation between pay duration and M\&A quality. Gopalan et al. (2014) finds mixed results on the relation between various governance proxies and executive compensation duration. Earlier literature has shown that corporate governance affects various aspects of M\&A decisions (e.g., Hoechle, Schmid, Walter, and Yermack (2012), Duchin and Schmid (2013), among many others). Thus, we investigate whether certain governance characteristics are associated with both long CEO pay duration and poor M\&A decisions. In addition, corporate governance may attenuate the negative relation between pay duration and M\&A performance. For example, CEOs from well-governed firms may be more likely to pursue M\&As to create long-term shareholder value, regardless of their pay duration.

\section{[Insert Table 9 about here]}

Following the literature, we use three measures that have been shown to be correlated with corporate governance: CEO tenure, CEO duality, and the percentage of the board comprised of co-opted independent directors. ${ }^{21}$ The sample size decreases due to data availability of director information. Table 9 reports regression results controlling for the three governance measures and their interactions with CEO pay duration. The other control variables in the performance regression specifications are the same as in Panel B of Tables 4, 5, and 6. To conserve space, we only report the coefficients on CEO compensation duration, the governance measures, and their interaction terms.

Columns (1) to (3) of Table 9 show that the coefficients on CEO compensation duration remain negative and significant. The results confirm that the negative relation between acquirer CEO pay duration and future M\&A performance persists after controlling for firm governance characteristics. The coefficients on the interaction terms between CEO pay duration and governance characteristics are mostly insignificant,

\footnotetext{
${ }^{21}$ Earlier studies have shown the CEOs could gradually gain power over boards through tenure (Hermalin and Weisbach (1998), Berger, Ofek, and Yermack (1997), Harford and Li (2007), among others). Researchers and activists have long argued that combining CEO and chairman responsibility would weaken board monitoring and corporate control (Fama and Jensen (1983), Lorsch and Yong (1990), Goyal and Park (2001), among others). Coles, Daniel and Naveen (2014) show that as the percentage of co-opted independent directors increases, board monitoring decreases. We thank Lalitha Naveen of Temple University for making the co-opted director data publicly available.
} 
suggesting that corporate governance does not change the negative relation. Overall, the results suggest that corporate governance characteristics do not contribute to, and cannot alleviate, the negative relation between CEO compensation duration and M\&A quality.

\section{B. Vesting Type and the Relation Between CEO Pay Duration and M\&A Quality}

Next, we examine whether the underlying vesting type of CEO incentive pay affects the relation between compensation duration and M\&A performance. CEO annual compensation duration is derived from both time-vesting and performance-vesting long-term incentive plans granted that year. However, these two types of grants may provide different incentives to executives. Earlier literature suggests that time-vesting grants provide insufficient incentives to CEOs, as the vesting of such grants is contingent only upon the passage of time (Bebchuk and Fried (2009), Gerakos, Ittner, and Larcker (2007)). In contrast, performance-vesting plans provide incentives for CEOs to improve the performance measures that are specified in the plan (Johnson and Tian (2000), Kuang (2006), Li and Wang (2016)). As a result, we expect that CEOs with long-term, time-vesting grants care less about the future performance impact of M\&As than do CEOs with long-term, performance-vesting grants.

\section{[Insert Figure 2 about here]}

We decompose CEO compensation duration into two components: duration of time-vesting grants and duration of performance-vesting grants. Figure 2 shows that after 2004, firms increasingly use performance-vesting grants to incentivize CEOs. By the end of our sample period in 2013, the percentage of firms using performance-vesting plans closely approximates the percentage of firms using time-vesting plans, consistent with the patterns documented in earlier literature (Bebchuk and Fried (2010), Angelis and Grinstein (2015), Li and Wang (2016)). On the individual grant level, the performance-vesting plans are of slightly longer duration, on average, than the time-vesting plans. As shown in Panel A of Table 1, within firms that use such incentives, the average duration of performance-vesting grants is 2.72 years, while the average duration of time-vesting grants is 2.56 years.

[Insert Table 10 about here] 
Table 10 reports the effect of time-vesting and performance-vesting compensation duration on M\&A performance. Each regression setting contains the same set of control variables as in the performance regressions in Panel B of Tables 4, 5, and 6. To conserve space, we report only the coefficients on time-vesting and performance-vesting compensation duration. The coefficients show that the acquirer CEO's time-vesting pay duration has a significant and negative correlation with the acquirer's three-day announcement CAR, post-M\&A change in abnormal ROA, and long-run abnormal stock performance. In contrast, Column (1) shows that the acquirer CEO's performance-vesting pay duration has a positive but insignificant correlation with M\&A announcement abnormal returns; Columns (2) and (3) show that acquirers with long performance-vesting pay duration CEOs do not experience worse longrun post-M\&A performance. The results suggest that the documented negative relation between compensation duration and M\&A performance is mainly driven by long-term time-vesting incentive pay. Consistent with earlier literature (Bebchuk and Fried (2009), Gerakos et al. (2007)), our findings suggest that, by itself, time-vesting pay does not provide adequate incentives for CEOs to create long-term firm value, and that extending CEO pay duration without including performance requirements negatively impacts firms' long-term investment decisions. If boards do grant long-duration pay to encourage CEOs to pursue M\&As, our results suggest that adding performance contingencies would result in better investment outcomes.

\section{Conclusion}

Despite a recent push for firms to lengthen CEO compensation duration in order to curb executive short-termism and promote long-term shareholder value, there is no empirical evidence on whether longer pay durations actually induce better investment decisions in the long term. In this paper, we fill this gap in the literature. Using a comprehensive measure of compensation duration, we find that CEOs with long pay duration are more likely to engage in large acquisitions. These acquisitions, however, receive significantly worse stock market reactions and experience lower post-M\&A abnormal operating and stock performance, compared with acquisitions conducted by CEOs with short pay duration. This negative relation between 
compensation duration and M\&A performance is unaffected by corporate governance and is robust to correcting for potential self-selection and endogeneity bias.

We find that the effect of CEO pay duration varies in different compensation plans. The documented negative relation between compensation duration and M\&A performance is mainly driven by long-term time-vesting contracts. In these time-vesting grants, the financial incentives are insufficient to improve executive performance, as payment is contingent only on the passage of time. In contrast, CEO pay duration in long-term performance-vesting plans is not associated with low quality M\&As, as these plans more closely link executive pay to future firm performance.

Overall, our study highlights that executive compensation duration is deeply intertwined with complicated contract designs, which may introduce conflicting incentives for managers. Thus, extending compensation duration, by itself, does not necessarily generate long-term firm value. This paper also suggests that boards need to carefully review the compensation structure and incentive motivations before extending compensation duration. 


\section{References}

Almazan, A.; A. De Motta; S. Titman; and V. Uysal. "Financial Structure, Aacquisition Opportunities, and Firm Locations." Journal of Finance, 65 (2010), 529-563.

Angelis, D., and Y. Grinstein. "Performance Terms in CEO Compensation Contracts." Review of Finance, 19 (2015), 619-651.

Barber, B., and J. Lyon. "Detecting Abnormal Operating Performance: the Empirical Power and Specification of Test Statistics." Journalof Financial Economics, 41 (1996), 359-99.

Barber, B., and J. Lyon. "Detecting Long-run Abnormal Stock Returns: The Empirical Power and Specification of Test Statistics." Journal of FinancialEconomics, 43 (1997), 341-72.

Barzuza, M., and E. Talley. "Long-Term Bias." Working Paper, Columbia University (2019).

Bebchuk, L., and J. Fried. "Pay without Performance: The Unfulfilled Promise of Executive Compensation." Harvard University Press (2009).

Bebchuk, L., and J. Fried. "Paying for Long-Term Performance.", University of Pennsylvania Law Review, 1915 (2010).

Berger, P.; E. Ofek; and D. Yermack. "Managerial Entrenchment and Capital Structure Decisions." Journal of Finance, 52 (1997), 1411-1438.

Bhagat, S., and R. Romano. "Reforming Executive Compensation: Focusing and Committing to the Long -term", Yale J. on Reg., 26 (2009), 359.

Bharath, S., and G. Wu. "Long-run Volatility and Risk Around Mergers and Acquisitions." Working Paper, Arizona State University (2005).

Bhagwat, V.; R. Dam; and J. Harford. "The Real Effects of Uncertainty on Merger Activity." Review of Financial Studies, 29 (2016), 3000-3034.

Brown, S., and J. Warner. "Using Daily Stock Returns." Journal of Financial Economics, 14 (1985), 3-31.

Chan, L.; K. Chen; and T. Chen. "The Effects of Firm-initiated Clawback Provisions on Bank Loan Contracting." Journal of Financial Economics, 110 (2013), 659-679.

Chang, S. "Takeovers of Privately Held Targets, Methods of Payment, and Bidder Returns." Journal of Finance 53 (1998), 773-784.

Chen, X.; J. Harford; and K. Li. "Monitoring: Which Institutions Matter?" Journal of Financial Economics, 86 (2007), 279-305.

Cheng, Q.; Y. Cho; and J. Kim. "Managers' Pay Duration and Voluntary Disclosures." Working paper, Singapore Management University (2014).

Chi, D.; M. Gupta.; and S. Johnson. "Short-horizon Incentives and Stock Price Inflation." Journal of Corporate Finance (2019), 101501.

Coles, J., N. Daniel; and L. Naveen. "Managerial Incentives and Risk-Taking." Journal of Financial Economics, 79 (2006), 431-468. 
Coles, J.; N, Daniel; and L, Naveen. "Co-opted Boards." Review of Financial Studies, 27 (2014), 17511796.

Datta, S.; M. Datta; and K. Raman. "Executive Compensation and Corporate Acquisition Decisions." Journal of Finance, 56 (2001), 2299-2336.

Dechow, P., and R. Sloan. "Executive Incentives and the Horizon Problem: An Empirical Investigation." Journal of Accounting and Economics, 14 (1991), 51-89.

Dehejia, R., and S.Wahba. "Propensity Score-matching Methods for Nonexperimental Causal Studies." Review of Economics and statistics, 84 (2002), 151-161.

Duchin, R., and B. Schmidt. "Riding the Merger Wave: Uncertainty, Reduced Monitoring, and Bad Acquisitions. Journal of Financial Economics, 107 (2013), 69-88.

Edmans, A.; V. Fang; and K. Lewellen. "Equity Vesting and Investment." Review of Financial Studies, 30 (2017), 2229-2271.

Edmans, A.; V. Fang; and A. Huang. "The Long-term Consequences of Short-Term Incentives." Working Paper, London Business School (2018).

Edmans, A., and X. Gabaix. "Executive Compensation: A Modern Primer." Journal of Economic literature, 54 (2016), 1232-87.

Fama, E., and M. Jensen. "Separation of Ownership and Control." Journal of Law and Economics, 26 (1983), 301-325.

Francis, B.; I. Hasan; K. John; and M. Waisman. "Urban Agglomeration and CEO Compensation." Journal of Financial and Quantitative Analysis, 51 (2016), 1925-1953.

Fu, F.; L. Lin; and M. Officer. "Acquisitions Driven by Stock Overvaluation: Are They Good Deals?" Journal of Financial Economics, 109 (2013), 24-39.

Gerakos, J; C. Ittner; and F. Larcker. "The Structure of Performance-Vested Stock Option Grants." Essays in Accounting Theory in Honor of Joel S. Demski. New York: Springer (2007), 227-249.

Golubov, A.; D. Petmezas; and N. Travlos. "When it Pays to Pay Your Investment Banker: New Evidence on the Role of Financial Advisors in M\&As." Journal of Finance, 67 (2012), 271-311.

Gopalan, R.; S. Huang; and J. Maharjan. "The Role of Deferred Pay in Retaining Managerial Talent." Working Paper, Washington University (2016).

Gopalan, R.; T. Milbourn; F. Song; and A. Thakor. "Duration of Executive Compensation." Journal of Finance, 69 (2014), 2777-2817.

Goyal, V., and C. Park. 2002. "Board Leadership Structure and CEO Turnover." Journal of Corporate Finance, 8 (2002), 49-66.

Grinstein, Y., and P. Hribar. "CEO Compensation and Incentives: Evidence from M\&A Bonuses." Journal of Financial Economics, 73 (2004), 119-143.

Harford, J., and K. Li. "Decoupling CEO Wealth and Firm Performance: The Case of Acquiring CEOs." Journal of Finance. 62 (2007), 917-949. 
Healy, P.; K. Palepu; and R. Ruback. "Does Corporate Performance Improve After Mergers?" Journal of Financial Economics, 31 (1992), 135-175

Heckman, J. "The Common Structure of Statistical Models of Truncation, Sample Selection, and Limited Dependent Variables and a Simple Estimator for Such Models." Annals of Economic and Social Measurement, 5 (1976), 475-492.

Heckman, J. "Sample Selection as A Specification Error." Econometrica. 47 (1979), 153-161.

Hermalin, B., and M. Weisbach. "Endogenously Chosen Boards of Birectors and Their Monitoring of the CEO." American Economic Review 88 (1998) 96-118.

Hirano, K.; G, Imbens; and G. Ridder. "Efficient Estimation of Average Treatment Effects Using the Estimated Propensity Score." Econometrica, 71 (2003), 1161-1189.

Hirst, D.; L. Koonce; and S.Venkataraman. "Management Earnings Forecasts: A Review and Framework." Accounting horizons, 22 (2008), 315-338.

Hoechle, D.; M. Schmid; I. Walter; and D.Yermack. "How Much of the Diversification Discount Can be Explained by Poor Corporate Governance?" Journal of Financial Economics, 103 (2012), 41-60.

Jensen, M.; K. Murphy; and E. Wruck. "Remuneration: Where We've Been, How We Got to Here, What are The Problems, and How to Fix Them." Working Paper, Harvard University (2004).

Johnson, S., and Y. Tian. "The Value and Incentive Effects of Nontraditional Executive Stock Option Plans." Journal of Financial Economics, 57 (2000), 3-34.

Kalyta, P. "Accounting Discretion, Horizon Problem, and CEO Retirement Benefits." Accounting Review, 84 (2009), 1553-1573.

Kay, T., and S. Putten. "Myths and Realities of Executive Pay." Cambridge University Press (2007).

Kuang, Y. "Incentive Effects of Performance-vested Stock Options." Working Paper, University of Melbourne (2006).

Li, K., and N. Prabhala. "Self-selection Models in Corporate Finance." in B. Espen Eckb, ed. Handbook of Corporate Finance (2006).

Li, K.; B. Qiu; and R. Shen. "Organizaiton Capital and Mergers and Acquisitions." Journal of Financial and Quantitative Analysis, 53 (2018), 1871-1909.

Li, Z., and L. Wang. "Executive Incentives Contingent on Long-term Accounting Performance." Review of Financial Studies 29 (2016), 1586-1633.

Lorsch, J., and J. Young. "Pawns or Potentates: The Reality of America's Corporate Boards." Academy of Management Perspectives, 4 (1990), 85-87.

Malmendier, U., and G. Tate. "Who Makes Acquisitions? CEO Overconfidence and the Market's Reaction." Journal of Financial Economics, 89 (2008), 20-43.

Masulis, R.; C. Wang; and F. Xie. "Corporate Governance and Acquirer Returns." Journal of Finance, 62 (2007): 1851-1889. 
Moeller, S.; F. Schlingemann; and R. Stulz. "Firm Size and the Gains from Acquisitions." Journal of Financial Economics, 73 (2004), 201-228.

Murphy, K. "Executive Compensation." Handbook of Labor Econmics (1999), 2485-2563.

Phan, H. "Inside Debt and Mergers and Acquisitions." Journal of Financial and Quantitative Analysis, 49 (2014), 1365-1401.

Pozen, R. "Curbing Short-termism in Corporate America: Focus on Executive Compensation." Governance Studies at Brookings, 35 (2014), 1-19.

Rosenbaum, P., and D. Rubin. "The Central Role of The Propensity Score in Observational Studies for Causal Effects." Biometrika. 70 (1983), 41-55.

Sundaram, R., and D. Yermack. "Pay Me Later: Inside Debt and Its Role in Managerial Compensation." Journal of Finance, 62 (2007), 1551-1588. 
Table 1. Summary Statistics

Panel A of the table presents summary statistics of CEO compensation for firms covered under Execucomp and ISS Incentive Lab from 1998 to 2013. Panel B presents summary statistics of firm and other CEO characteristics for all firm years covered under Execucomp and ISS Incentive Lab from 1998 to 2013. See Appendix A for detailed variable definitions. All dollar values are converted to constant 2006 dollars. All non-binary variables are winsorized at $1 \%$ and $99 \%$.

\begin{tabular}{|c|c|c|c|c|}
\hline Panel A. CEO compensation & Obs & Mean & Median & Std Dev \\
\hline TOTAL_COMPENSATION (\$ thousand) & 14,987 & 7,296 & 5,025 & 7,595 \\
\hline SALARY $(\$$ thousand $)$ & 14,987 & 857 & 841 & 369 \\
\hline BONUS ( $\$$ thousand) & 14,987 & 714 & 85 & 1,331 \\
\hline OPTION ( $\$$ thousand) & 14,987 & 3,817 & 1,365 & 7,896 \\
\hline RESTRICTED_STOCK ( $\$$ thousand) & 14,987 & 2,148 & 619 & 4,166 \\
\hline COMPENSATION_DURATION (years) & 14,987 & 1.511 & 1.585 & 0.874 \\
\hline PORTFOLIO_DURAITON (years) & 14,987 & 0.679 & 0.580 & 0.583 \\
\hline OPTION_DURATION (years) & 14,987 & 1.739 & 2.000 & 1.350 \\
\hline STOCK_DURATION (years) & 14,987 & 1.527 & 1.471 & 1.551 \\
\hline LONG-T̄ERM_NON-EQUITY_DURATION (years) & 14,987 & 0.295 & 0.000 & 0.904 \\
\hline PERFORMANCE-VESTING_DURATION (years) & 14,987 & 1.184 & 0.000 & 1.511 \\
\hline TIME-VESTING_DURATION (years) & 14,987 & 2.085 & 2.352 & 1.263 \\
\hline \multicolumn{5}{|l|}{ Duration in firm-years with no-missing Grants } \\
\hline OPTION_DURAITON (years) & 10,576 & 2.464 & 2.500 & 0.892 \\
\hline RESTRICTED_STOCK_DURATION (years) & 8,721 & 2.754 & 3.000 & 1.009 \\
\hline LONG-TERM_NON-EQUITY_DURATION (years) & 1,520 & 2.910 & 3.000 & 0.674 \\
\hline PERFORMANCE-VESTING_DURATION (years) & 6,520 & 2.723 & 3.000 & 1.030 \\
\hline TIME-VESTING_DURATION (years) & 12,208 & 2.561 & 2.500 & 0.862 \\
\hline Panel B. Firm and CEO characteristics & Obs & Mean & Median & Std Dev \\
\hline TOTAL_ASSETS (\$ million) & 14,987 & 18,878 & 4,451 & 50,048 \\
\hline TOTAL_SALES ( $\$$ million) & 14,987 & 8,555 & 3,022 & 15,816 \\
\hline LEVERĀGE & 14,987 & 0.229 & 0.221 & 0.165 \\
\hline FIRM_Q & 14,987 & 1.972 & 1.497 & 1.359 \\
\hline LONG-TERM_ASSETS & 14,987 & 0.415 & 0.423 & 0.246 \\
\hline R\&D_EXPENS̄E & 14,987 & 0.025 & 0.000 & 0.047 \\
\hline CASH_FLOW & 14,987 & 0.090 & 0.081 & 0.122 \\
\hline ROA & 14,987 & 0.152 & 0.139 & 0.108 \\
\hline ROE & 14,987 & 0.105 & 0.117 & 0.247 \\
\hline PRIOR_YEAR_RETURN & 14,987 & 0.183 & 0.109 & 0.697 \\
\hline SALE_GROWTH & 14,987 & 0.107 & 0.075 & 0.236 \\
\hline CASH_VOLATILITY & 14,987 & 0.053 & 0.036 & 0.054 \\
\hline INTERIM_INDUSTRY_UNCERTAINTY & 14,987 & 0.844 & 0.858 & 0.208 \\
\hline FIRM_AGE (years) & 14,987 & 29.258 & 25.000 & 17.731 \\
\hline HERFINDAHL_INDEX & 14,987 & 0.223 & 0.167 & 0.187 \\
\hline CEO_OVERCONFIDENCE & 14,987 & 0.270 & 0.000 & 0.444 \\
\hline CEO_SHAREHOLDINGS (\%) & 14,638 & 0.000 & 0.000 & 0.000 \\
\hline CEO_AGE (years) & 14,559 & 55.663 & 56.000 & 7.025 \\
\hline CEO_TEUNURE (years) & 13,237 & 7.341 & 5.671 & 6.584 \\
\hline CEO_DUALITY & 13,237 & 0.628 & 1.000 & 0.483 \\
\hline CO-OPTED_BOARD & 11,791 & 0.455 & 0.417 & 0.308 \\
\hline
\end{tabular}


Table 2. Distribution and Descriptive Statistics of M\&A Deals, 1999-2013

Panel A of the Table presents annual distribution of 1,222 completed acquisitions announced during 1999 to 2013. We restrict the sample to deals with transaction values of at least $\$ 1$ million and that account for more than $1 \%$ of the acquirer's size, and with valid accounting, stock, and CEO compensation information. Panel B presents summary statistics of deal characteristics. See Appendix A for detailed variable definitions. All dollar values are converted to constant 2006 dollars. All non-binary variables are winsorized at $1 \%$ and $99 \%$. $* * *$, and $* * *$ indicate significance at the $10 \%, 5 \%$, and $1 \%$ levels, respectively.

\begin{tabular}{ccccc}
\hline \multicolumn{6}{l}{ Panel A: Distribution of M\&A deals by year } & & & \\
\hline $\begin{array}{c}\text { Announcement } \\
\text { year }\end{array}$ & $\begin{array}{c}\text { Number of } \\
\text { acquisitions }\end{array}$ & $\begin{array}{c}\text { Number of } \\
\text { acquirers }\end{array}$ & \% of acquisition sample & $\%$ of firm sample \\
\hline 1999 & 149 & 125 & $12.19 \%$ & $11.18 \%$ \\
2000 & 160 & 131 & $13.09 \%$ & $11.72 \%$ \\
2001 & 99 & 92 & $8.10 \%$ & $8.23 \%$ \\
2002 & 63 & 59 & $5.16 \%$ & $5.28 \%$ \\
2003 & 84 & 79 & $6.87 \%$ & $7.07 \%$ \\
2004 & 94 & 84 & $7.69 \%$ & $7.51 \%$ \\
2005 & 91 & 86 & $7.45 \%$ & $7.69 \%$ \\
2006 & 73 & 68 & $5.97 \%$ & $6.08 \%$ \\
2007 & 85 & 82 & $6.96 \%$ & $7.33 \%$ \\
2008 & 58 & 57 & $4.75 \%$ & $5.10 \%$ \\
2009 & 56 & 51 & $4.58 \%$ & $4.56 \%$ \\
2010 & 66 & 63 & $5.40 \%$ & $5.64 \%$ \\
2011 & 54 & 53 & $4.42 \%$ & $4.74 \%$ \\
2012 & 49 & 48 & $4.01 \%$ & $4.29 \%$ \\
2013 & 41 & 40 & $3.36 \%$ & $3.58 \%$ \\
Total & 1,222 & 1,118 & $100 \%$ & $100 \%$ \\
\hline
\end{tabular}




\begin{tabular}{|c|c|c|c|c|c|c|c|c|c|c|c|c|}
\hline \multicolumn{13}{|l|}{ Panel B. Deal characteristics } \\
\hline & \multicolumn{4}{|c|}{ Full sample } & \multicolumn{3}{|c|}{ Long duration subsample } & \multicolumn{3}{|c|}{ Short duration subsample } & \multicolumn{2}{|c|}{ Long-Short } \\
\hline & Obs & Mean & Median & Std Dev & Mean & Median & Std Dev & Mean & Median & Std Dev & $\begin{array}{l}\text { Dif.in } \\
\text { Mean } \\
\end{array}$ & $\begin{array}{l}\text { Dif. in } \\
\text { Median }\end{array}$ \\
\hline DEAL_VALUE (\$ million) & 1,222 & 2,674 & 687 & 5,761 & 3,051 & 733 & 6,410 & 2,298 & 570 & 5,007 & $752 * *$ & $162 * *$ \\
\hline RELATIVE_DEAL_SIZE & 1,222 & 0.175 & 0.071 & 0.304 & 0.174 & 0.073 & 0.350 & 0.175 & 0.070 & 0.249 & -0.001 & 0.00 \\
\hline ALL_CASH & 1,222 & 0.317 & 0.000 & 0.465 & 0.301 & 0.000 & 0.459 & 0.332 & 0.000 & 0.471 & -0.031 & 0.00 \\
\hline DIVERSIFIED_M\&A & 1,222 & 0.548 & 1.000 & 0.498 & 0.555 & 1.000 & 0.497 & 0.542 & 1.000 & 0.499 & 0.013 & 0.00 \\
\hline HOSTILE & 1,222 & 0.007 & 0.000 & 0.0855 & 0.006 & 0.000 & 0.081 & 0.008 & 0.000 & 0.090 & -0.002 & 0.00 \\
\hline TENDER & 1,222 & 0.119 & 0.000 & 0.324 & 0.113 & 0.000 & 0.317 & 0.126 & 0.000 & 0.332 & -0.013 & 0.00 \\
\hline PUBLIC_TARGET & 1,222 & 0.642 & 1.000 & 0.480 & 0.638 & 1.000 & 0.481 & 0.645 & 1.000 & 0.479 & -0.007 & 0.00 \\
\hline
\end{tabular}


Table 3. CEO Compensation Duration and Acquisition Propensity

This table reports the probit regression results of acquisition propensities. The dependent variable is a binary variable set to one if a firm announces an acquisition in year $t$ with the deal value exceeding $1 \%$ of the acquiring firm's market value of total assets and at least $\$ 1$ million at the end of year $t-1$, and zero otherwise. Columns (1) and (2) present probit regression results with CEO compensation duration and portfolio duration, respectively. Columns (3) and (4) present marginal effects estimated at the mean for continuous variables and for a change in indicator variables from zero to one. All firm- and CEO-level explanatory variables are measured at the end of the fiscal year before the M\&A announcement. All non-binary variables are winsorized at $1 \%$ and $99 \%$. All regressions include year and industry fixed effects based on Fama-French 48 classification. See detailed variable definitions in Appendix A. Heteroscedasticity-robust standard errors clustered by firms are reported in parentheses. *, **, and *** indicate significance at the $10 \%, 5 \%$, and $1 \%$ levels, respectively.

\begin{tabular}{|c|c|c|c|c|}
\hline \multirow[b]{3}{*}{ COMPENSATION_DURATION } & \multicolumn{2}{|c|}{ Probit coefficients } & \multicolumn{2}{|c|}{ Marginal effects } \\
\hline & 1 & 2 & 3 & 4 \\
\hline & $\begin{array}{c}0.050 * * * \\
(0.019)\end{array}$ & & $\begin{array}{c}0.005 * * * \\
(0.002)\end{array}$ & \\
\hline PORTFOLIO_DURATION & & $\begin{array}{c}0.075^{* * * *} \\
(0.027)\end{array}$ & & $\begin{array}{c}0.008 * * * \\
(0.003)\end{array}$ \\
\hline CEO_OVERCONFIDENCE & $\begin{array}{l}0.074 * \\
(0.042)\end{array}$ & $\begin{array}{c}0.101 * * \\
(0.044)\end{array}$ & $\begin{array}{l}0.008^{*} \\
(0.005)\end{array}$ & $\begin{array}{c}0.011 * * \\
(0.005)\end{array}$ \\
\hline Log(TOTAL_ASSETS) & $\begin{array}{c}0.075^{* * *} * \\
(0.016)\end{array}$ & $\begin{array}{c}0.080 * * * \\
(0.016)\end{array}$ & $\begin{array}{c}0.008 * * * \\
(0.002)\end{array}$ & $\begin{array}{c}0.009 * * * \\
(0.002)\end{array}$ \\
\hline ROA & $\begin{array}{c}1.024 * * * \\
(0.211)\end{array}$ & $\begin{array}{c}1.015^{* * *} * \\
(0.210)\end{array}$ & $\begin{array}{c}0.111 * * * \\
(0.023)\end{array}$ & $\begin{array}{c}0.109 * * * \\
(0.023)\end{array}$ \\
\hline FIRM_Q & $\begin{array}{l}-0.022 \\
(0.017)\end{array}$ & $\begin{array}{l}-0.017 \\
(0.017)\end{array}$ & $\begin{array}{l}-0.002 \\
(0.002)\end{array}$ & $\begin{array}{l}-0.002 \\
(0.002)\end{array}$ \\
\hline PRIOR_YEAR_RETURN & $\begin{array}{c}0.161^{* * * *} \\
(0.035)\end{array}$ & $\begin{array}{c}0.157^{* * * *} \\
(0.035)\end{array}$ & $\begin{array}{c}0.017 * * * \\
(0.004)\end{array}$ & $\begin{array}{c}0.017 * * * \\
(0.004)\end{array}$ \\
\hline SALE_GROWTH & $\begin{array}{c}0.265^{* * * *} \\
(0.070)\end{array}$ & $\begin{array}{c}0.275^{* * * *} \\
(0.070)\end{array}$ & $\begin{array}{c}0.029 * * * \\
(0.008)\end{array}$ & $\begin{array}{c}0.030^{* * *} \\
(0.008)\end{array}$ \\
\hline LEVERAGE & $\begin{array}{c}-0.282^{* *} \\
(0.127)\end{array}$ & $\begin{array}{c}-0.280 * * \\
(0.126)\end{array}$ & $\begin{array}{c}-0.030 * * \\
(0.014)\end{array}$ & $\begin{array}{c}-0.030 * * \\
(0.014)\end{array}$ \\
\hline LONG-TERM_ASSETS & $\begin{array}{c}0.246^{* *} \\
(0.115)\end{array}$ & $\begin{array}{c}0.253^{* *} \\
(0.116)\end{array}$ & $\begin{array}{c}0.026 * * \\
(0.012)\end{array}$ & $\begin{array}{c}0.027 * * \\
(0.012)\end{array}$ \\
\hline CASH_FLOW & $\begin{array}{c}-0.667 * * * \\
(0.146)\end{array}$ & $\begin{array}{c}-0.664 * * * * \\
(0.145)\end{array}$ & $\begin{array}{c}-0.072 * * * \\
(0.016)\end{array}$ & $\begin{array}{c}-0.072 * * * \\
(0.016)\end{array}$ \\
\hline CASH_VOLATILITY & $\begin{array}{c}0.838^{* * *} \\
(0.376)\end{array}$ & $\begin{array}{c}0.849^{* *} \\
(0.375)\end{array}$ & $\begin{array}{c}0.090^{* *} \\
(0.041)\end{array}$ & $\begin{array}{c}0.092^{* *} \\
(0.040)\end{array}$ \\
\hline INTERIM_INDUSTRY_UNCERTAINTY & $\begin{array}{c}-0.337 * * * \\
(0.122)\end{array}$ & $\begin{array}{c}-0.334 * * * \\
(0.122)\end{array}$ & $\begin{array}{c}-0.036 * * * \\
(0.013)\end{array}$ & $\begin{array}{c}-0.036 * * * \\
(0.013)\end{array}$ \\
\hline FIRM_AGE & $\begin{array}{c}-0.084 * * * \\
(0.030)\end{array}$ & $\begin{array}{c}-0.085 * * * \\
(0.030)\end{array}$ & $\begin{array}{c}-0.009 * * * \\
(0.003)\end{array}$ & $\begin{array}{c}-0.009 * * * \\
(0.003)\end{array}$ \\
\hline HERFINDAHL_INDEX & $\begin{array}{l}-0.214^{*} \\
(0.126)\end{array}$ & $\begin{array}{c}-0.215^{*} \\
(0.126)\end{array}$ & $\begin{array}{c}-0.023^{*} \\
(0.014)\end{array}$ & $\begin{array}{l}-0.023^{*} \\
(0.014)\end{array}$ \\
\hline Constant & $\begin{array}{c}-1.019 * * \\
(0.423)\end{array}$ & $\begin{array}{c}-1.037 * * \\
(0.417)\end{array}$ & & \\
\hline Ind. and Yr. FE & Yes & Yes & & \\
\hline $\begin{array}{l}\text { Pseudo- } R^{2} \\
\text { Observations }\end{array}$ & $\begin{array}{c}0.084 \\
14.987\end{array}$ & $\begin{array}{c}0.084 \\
14.987\end{array}$ & & \\
\hline
\end{tabular}




\section{Table 4. CEO Compensation Duration, Market Announcement Return, and Merger Premium}

Panel A of this table reports market reaction around the M\&A announcement date. We separate the sample into subgroups based on median acquirer CEO compensation duration measured at the fiscal year end proceeding to M\&A announcements. Cumulative abnormal returns (CARs) over a three-day window around the M\&A announcement dates are estimated using the Fama-French three-factor model. The parameters of the three-factor model are estimated based on daily stock returns from trading days -255 to -46 with at least 30 non-missing daily stock returns. Columns (1) to (7) of Panel A report CARs for the full sample, the above median (long) acquirer CEO compensation duration subsample, and the below median (short) acquirer CEO compensation duration subsample. The last two columns report the differences in mean/median between long and short duration groups, with $P$-values from t-test/Wilcoxon Signed-rank test reported in parentheses. Panel B presents results from regressions of acquirer abnormal announcement returns on CEO pay duration. The dependent variable is the acquirers' three-day CARs around M\&A announcements. Panel C presents results from regressions of merger premiums on CEO pay duration. The dependent variable is the target firm's merger premium measured as the value of the deal divided by market value of the target firm at least 40 days prior to the merger announcement day. Columns (1) and (2) of Panel B and Panel C report results from baseline OLS regressions. Columns (3) and (4) of Panel B and Panel C report the second-stage results from the Heckman selection model. All firm- and CEO-level explanatory variables are measured at the end of the fiscal year before M\&A announcement. See detailed variable definitions in Appendix A. All regressions include year and industry fixed effects based on Fama-French 48 classification. Heteroscedasticity-robust standard errors clustered by firms are reported in parentheses. *,**, and $* * *$ indicate significance at the $10 \%, 5 \%$, and $1 \%$ levels, respectively.

\begin{tabular}{|c|c|c|c|c|c|c|c|c|c|}
\hline \multicolumn{10}{|c|}{ Panel A. Univariate analysis on market reaction around M\&A announcement date } \\
\hline \multirow[t]{3}{*}{ CARs } & \multicolumn{3}{|c|}{ Full sample } & \multicolumn{2}{|c|}{ Long compensation duration } & \multicolumn{2}{|c|}{ Short compensation duration } & \multicolumn{2}{|c|}{ Long-Short } \\
\hline & 1 & 2 & 3 & 4 & 5 & 6 & 7 & 8 & 9 \\
\hline & Obs. & Mean & Median & Mean & Median & Mean & Median & $\begin{array}{l}\text { Dif. in } \\
\text { Mean }\end{array}$ & $\begin{array}{l}\text { Dif. in } \\
\text { Median }\end{array}$ \\
\hline $\begin{array}{c}\text { Acquirer } \\
{[-1,+1]}\end{array}$ & 1,157 & $\begin{array}{c}-0.97 \% * * * \\
(0.00)\end{array}$ & $\begin{array}{c}-0.72 \% * * * \\
(0.00)\end{array}$ & $\begin{array}{c}-1.34 \% * * * \\
(0.00)\end{array}$ & $\begin{array}{c}-0.97 \% * * * \\
(0.01)\end{array}$ & $\begin{array}{c}-0.59 \% * * \\
(0.04)\end{array}$ & $\begin{array}{c}-0.46 \% * * * \\
(0.00)\end{array}$ & $\begin{array}{c}-0.75 \% * \\
(0.08)\end{array}$ & $\begin{array}{c}-0.51 \% * \\
(0.07)\end{array}$ \\
\hline $\begin{array}{l}\text { Target } \\
{[-1,+1]}\end{array}$ & 694 & $\begin{array}{c}24.16 \% * * * \\
(0.00)\end{array}$ & $\begin{array}{c}20.31 \% * * * \\
(0.00)\end{array}$ & $\begin{array}{c}22.87 \% * * * \\
(0.00)\end{array}$ & $\begin{array}{c}20.04 \% * * * \\
(0.00)\end{array}$ & $\begin{array}{c}25.46 \% * * * \\
(0.00)\end{array}$ & $\begin{array}{c}21.05 \% * * * \\
(0.00)\end{array}$ & $\begin{array}{c}-2.59 \% \\
(0.13)\end{array}$ & $\begin{array}{c}-1.01 \% \\
(0.27)\end{array}$ \\
\hline
\end{tabular}




\begin{tabular}{|c|c|c|c|c|}
\hline \multicolumn{5}{|c|}{ Panel B. Multivariate regression on acquirer's three-day CARs around M\&A announcement date } \\
\hline & \multicolumn{2}{|c|}{ OLS } & \multicolumn{2}{|c|}{ Heckman } \\
\hline & 1 & 2 & 3 & 4 \\
\hline COMPENSATION_DURATION & $\begin{array}{c}-0.565 * * \\
(0.284)\end{array}$ & & $\begin{array}{c}-0.722^{* *} \\
(0.314)\end{array}$ & \\
\hline PORTFOLIO_DURAITON & & $\begin{array}{l}-0.881 * \\
(0.481)\end{array}$ & & $\begin{array}{c}-1.102 * * \\
(0.496)\end{array}$ \\
\hline CEO_OVERCONFIDENCE & $\begin{array}{c}0.452 \\
(0.547)\end{array}$ & $\begin{array}{c}0.110 \\
(0.584)\end{array}$ & $\begin{array}{c}0.326 \\
(0.621)\end{array}$ & $\begin{array}{l}-0.064 \\
(0.683)\end{array}$ \\
\hline $\log ($ TOTAL_ASSETS $)$ & $\begin{array}{l}-0.338 \\
(0.216)\end{array}$ & $\begin{array}{c}-0.402^{*} \\
(0.210)\end{array}$ & $\begin{array}{l}-0.327 \\
(0.243)\end{array}$ & $\begin{array}{l}-0.400^{*} \\
(0.240)\end{array}$ \\
\hline ROA & $\begin{array}{c}3.235 \\
(2.273)\end{array}$ & $\begin{array}{c}3.262 \\
(2.236)\end{array}$ & $\begin{array}{l}4.460 \\
(3.906)\end{array}$ & $\begin{array}{c}4.594 \\
(3.903)\end{array}$ \\
\hline FIRM_Q & $\begin{array}{l}-0.005 \\
(0.063)\end{array}$ & $\begin{array}{l}-0.020 \\
(0.061)\end{array}$ & $\begin{array}{l}-0.128 \\
(0.116)\end{array}$ & $\begin{array}{l}-0.139 \\
(0.116)\end{array}$ \\
\hline PRIOR_YEAR_RETURN & $\begin{array}{l}-0.025 \\
(0.542)\end{array}$ & $\begin{array}{c}0.050 \\
(0.536)\end{array}$ & $\begin{array}{c}0.067 \\
(0.815)\end{array}$ & $\begin{array}{c}0.174 \\
(0.811)\end{array}$ \\
\hline CEO_AGE & $\begin{array}{l}-2.016 \\
(2.007)\end{array}$ & $\begin{array}{l}-2.107 \\
(2.023)\end{array}$ & $\begin{array}{l}-2.311 \\
(2.067)\end{array}$ & $\begin{array}{l}-2.450 \\
(2.065)\end{array}$ \\
\hline CEO_SHAREHOLDINGS & $\begin{array}{c}0.027 \\
(0.054)\end{array}$ & $\begin{array}{c}0.013 \\
(0.054)\end{array}$ & $\begin{array}{c}0.024 \\
(0.055)\end{array}$ & $\begin{array}{c}0.010 \\
(0.056)\end{array}$ \\
\hline ANNUAL_COMPENSATION & $\begin{array}{c}0.029 \\
(0.077)\end{array}$ & $\begin{array}{c}0.012 \\
(0.078)\end{array}$ & $\begin{array}{c}0.047 \\
(0.081)\end{array}$ & $\begin{array}{c}0.022 \\
(0.083)\end{array}$ \\
\hline RELATIVE_DEAL_SIZE & $\begin{array}{l}-2.576 \\
(1.742)\end{array}$ & $\begin{array}{c}-2.451 \\
(1.748)\end{array}$ & $\begin{array}{l}-2.633 \\
(1.742)\end{array}$ & $\begin{array}{l}-2.453 \\
(1.747)\end{array}$ \\
\hline ALL_CASH & $\begin{array}{c}0.421 \\
(0.528)\end{array}$ & $\begin{array}{c}0.437 \\
(0.529)\end{array}$ & $\begin{array}{c}0.498 \\
(0.529)\end{array}$ & $\begin{array}{c}0.513 \\
(0.532)\end{array}$ \\
\hline HOSTILE & $\begin{array}{l}-0.430 \\
(1.899)\end{array}$ & $\begin{array}{l}-0.370 \\
(1.908)\end{array}$ & $\begin{array}{l}-0.331 \\
(1.840)\end{array}$ & $\begin{array}{l}-0.285 \\
(1.867)\end{array}$ \\
\hline TENDER & $\begin{array}{c}0.014 \\
(0.716)\end{array}$ & $\begin{array}{c}0.093 \\
(0.728)\end{array}$ & $\begin{array}{l}-0.149 \\
(0.729)\end{array}$ & $\begin{array}{l}-0.054 \\
(0.745)\end{array}$ \\
\hline PUBLIC_TARGET & $\begin{array}{c}-1.922 * * * * \\
(0.597)\end{array}$ & $\begin{array}{c}-1.893^{* * * *} \\
(0.595)\end{array}$ & $\begin{array}{c}-1.786^{* * * *} \\
(0.589)\end{array}$ & $\begin{array}{c}-1.759 * * * \\
(0.586)\end{array}$ \\
\hline DIVERSIFIED_M\&A & $\begin{array}{c}0.569 \\
(0.527)\end{array}$ & $\begin{array}{c}0.630 \\
(0.526)\end{array}$ & $\begin{array}{c}0.634 \\
(0.531)\end{array}$ & $\begin{array}{c}0.702 \\
(0.532)\end{array}$ \\
\hline HERFINDAHL_INDEX & $\begin{array}{c}2.454 \\
(1.912)\end{array}$ & $\begin{array}{c}2.218 \\
(1.919)\end{array}$ & $\begin{array}{c}2.092 \\
(2.003)\end{array}$ & $\begin{array}{c}1.770 \\
(2.008)\end{array}$ \\
\hline INVERSE_MILLS_RATIO & & & $\begin{array}{l}-1.272 \\
(2.669)\end{array}$ & $\begin{array}{l}-0.953 \\
(2.625)\end{array}$ \\
\hline Constant & $\begin{array}{l}11.052 \\
(8.069)\end{array}$ & $\begin{array}{l}11.572 \\
(8.187)\end{array}$ & $\begin{array}{l}14.342 \\
(9.884)\end{array}$ & $\begin{array}{c}14.648 \\
(10.000)\end{array}$ \\
\hline $\begin{array}{l}\text { Ind. and Yr. FE } \\
R^{2} \\
\text { Observations }\end{array}$ & $\begin{array}{c}\text { Yes } \\
0.118 \\
1,067\end{array}$ & $\begin{array}{l}\text { Yes } \\
0.118 \\
1,067\end{array}$ & $\begin{array}{c}\text { Yes } \\
0.122 \\
1,045 \\
\end{array}$ & $\begin{array}{c}\text { Yes } \\
0.122 \\
1,045 \\
\end{array}$ \\
\hline
\end{tabular}




\begin{tabular}{|c|c|c|c|c|}
\hline \multicolumn{5}{|c|}{ Panel C. Multivariate regression on merger premium } \\
\hline & \multicolumn{2}{|c|}{ OLS } & \multicolumn{2}{|c|}{ Heckman } \\
\hline & 1 & 2 & 3 & 4 \\
\hline COMPENSATION_DURATION & $\begin{array}{c}0.075 \\
(0.062)\end{array}$ & & $\begin{array}{c}0.097 \\
(0.069)\end{array}$ & \\
\hline PORTFOLIO_DURATION & & $\begin{array}{l}-0.057 \\
(0.063)\end{array}$ & & $\begin{array}{l}-0.061 \\
(0.064)\end{array}$ \\
\hline CEO_OVERCONFIDENCE & $\begin{array}{c}-0.108^{*} \\
(0.059)\end{array}$ & $\begin{array}{c}-0.103^{*} \\
(0.061)\end{array}$ & $\begin{array}{l}-0.115^{*} \\
(0.063)\end{array}$ & $\begin{array}{l}-0.094 \\
(0.071)\end{array}$ \\
\hline $\log ($ TOTAL_ASSETS $)$ & $\begin{array}{l}-0.050 \\
(0.032)\end{array}$ & $\begin{array}{l}-0.029 \\
(0.028)\end{array}$ & $\begin{array}{l}-0.053^{*} \\
(0.031)\end{array}$ & $\begin{array}{l}-0.024 \\
(0.031)\end{array}$ \\
\hline ROA & $\begin{array}{c}0.292 \\
(0.535)\end{array}$ & $\begin{array}{c}0.311 \\
(0.532)\end{array}$ & $\begin{array}{c}0.210 \\
(0.479)\end{array}$ & $\begin{array}{c}0.331 \\
(0.464)\end{array}$ \\
\hline FIRM_Q & $\begin{array}{l}-0.008 \\
(0.014)\end{array}$ & $\begin{array}{l}-0.006 \\
(0.013)\end{array}$ & $\begin{array}{l}-0.008 \\
(0.027)\end{array}$ & $\begin{array}{l}-0.012 \\
(0.027)\end{array}$ \\
\hline PRIOR_YEAR_RETURN & $\begin{array}{c}0.087 \\
(0.103)\end{array}$ & $\begin{array}{c}0.080 \\
(0.100)\end{array}$ & $\begin{array}{c}0.105 \\
(0.141)\end{array}$ & $\begin{array}{c}0.120 \\
(0.144)\end{array}$ \\
\hline CEO_AGE & $\begin{array}{c}0.624 \\
(0.656)\end{array}$ & $\begin{array}{c}0.507 \\
(0.603)\end{array}$ & $\begin{array}{c}0.587 \\
(0.662)\end{array}$ & $\begin{array}{c}0.444 \\
(0.607)\end{array}$ \\
\hline CEO_SHAREHOLDINGS & $\begin{array}{c}0.008 \\
(0.007)\end{array}$ & $\begin{array}{c}0.003 \\
(0.009)\end{array}$ & $\begin{array}{c}0.010 \\
(0.007)\end{array}$ & $\begin{array}{c}0.004 \\
(0.009)\end{array}$ \\
\hline ANNUAL_COMPENSATION & $\begin{array}{c}0.008 \\
(0.009)\end{array}$ & $\begin{array}{c}0.012 \\
(0.009)\end{array}$ & $\begin{array}{c}0.007 \\
(0.009)\end{array}$ & $\begin{array}{c}0.012 \\
(0.010)\end{array}$ \\
\hline RELATIVE_DEAL_SIZE & $\begin{array}{c}-0.334 * * \\
(0.157)\end{array}$ & $\begin{array}{c}-0.321 * * \\
(0.154)\end{array}$ & $\begin{array}{l}-0.213 \\
(0.134)\end{array}$ & $\begin{array}{l}-0.202 \\
(0.131)\end{array}$ \\
\hline ALL_CASH & $\begin{array}{c}-0.152 * * \\
(0.077)\end{array}$ & $\begin{array}{l}-0.145^{*} \\
(0.077)\end{array}$ & $\begin{array}{l}-0.127^{*} \\
(0.077)\end{array}$ & $\begin{array}{l}-0.119 \\
(0.076)\end{array}$ \\
\hline HOSTILE & $\begin{array}{l}-0.128 \\
(0.168)\end{array}$ & $\begin{array}{l}-0.122 \\
(0.169)\end{array}$ & $\begin{array}{l}-0.142 \\
(0.171)\end{array}$ & $\begin{array}{l}-0.132 \\
(0.169)\end{array}$ \\
\hline TENDER & $\begin{array}{c}0.097 \\
(0.077)\end{array}$ & $\begin{array}{c}0.086 \\
(0.080)\end{array}$ & $\begin{array}{c}0.109 \\
(0.077)\end{array}$ & $\begin{array}{c}0.097 \\
(0.080)\end{array}$ \\
\hline PUBLIC_TARGET & $\begin{array}{c}0.100 \\
(0.302)\end{array}$ & $\begin{array}{c}0.133 \\
(0.297)\end{array}$ & $\begin{array}{c}0.084 \\
(0.299)\end{array}$ & $\begin{array}{c}0.125 \\
(0.292)\end{array}$ \\
\hline DIVERSIFIED_M\&A & $\begin{array}{c}-0.209^{* *} \\
(0.103)\end{array}$ & $\begin{array}{c}-0.197 * * \\
(0.100)\end{array}$ & $\begin{array}{c}-0.224 * * \\
(0.113)\end{array}$ & $\begin{array}{l}-0.211^{*} \\
(0.109)\end{array}$ \\
\hline HERFINDAHL_INDEX & $\begin{array}{c}0.127 \\
(0.228)\end{array}$ & $\begin{array}{c}0.142 \\
(0.231)\end{array}$ & $\begin{array}{c}0.167 \\
(0.227)\end{array}$ & $\begin{array}{c}0.174 \\
(0.230)\end{array}$ \\
\hline TARGET_ROA & $\begin{array}{l}-0.032 \\
(0.023)\end{array}$ & $\begin{array}{l}-0.032 \\
(0.023)\end{array}$ & $\begin{array}{l}-0.033 \\
(0.025)\end{array}$ & $\begin{array}{l}-0.031 \\
(0.025)\end{array}$ \\
\hline TARGET_FIRM_Q & $\begin{array}{l}-0.350^{*} \\
(0.183)\end{array}$ & $\begin{array}{c}-0.337 * \\
(0.183)\end{array}$ & $\begin{array}{c}-0.372 * * \\
(0.187)\end{array}$ & $\begin{array}{l}-0.360^{*} \\
(0.184)\end{array}$ \\
\hline TARGET_PRIOR_YEAR_RETURN & $\begin{array}{l}-0.034 \\
(0.031)\end{array}$ & $\begin{array}{l}-0.030 \\
(0.033)\end{array}$ & $\begin{array}{l}-0.035 \\
(0.034)\end{array}$ & $\begin{array}{l}-0.031 \\
(0.036)\end{array}$ \\
\hline INVERSE_MILLS_RATIO & & & $\begin{array}{c}0.055 \\
(0.348)\end{array}$ & $\begin{array}{c}0.146 \\
(0.365)\end{array}$ \\
\hline Constant & $\begin{array}{l}-0.309 \\
(2.486)\end{array}$ & $\begin{array}{c}0.082 \\
(2.319)\end{array}$ & $\begin{array}{l}-0.259 \\
(2.959)\end{array}$ & $\begin{array}{c}0.012 \\
(2.837)\end{array}$ \\
\hline $\begin{array}{l}\text { Ind. and Yr. FE } \\
R^{2} \\
\text { Observations }\end{array}$ & $\begin{array}{c}\text { Yes } \\
0.243 \\
639 \\
\end{array}$ & $\begin{array}{c}\text { Yes } \\
0.240 \\
639 \\
\end{array}$ & $\begin{array}{c}\text { Yes } \\
0.285 \\
627 \\
\end{array}$ & $\begin{array}{c}\text { Yes } \\
0.280 \\
627 \\
\end{array}$ \\
\hline
\end{tabular}




\section{Table 5. CEO Compensation Duration and Post-M\&A Long-Run Abnormal Operating Performance}

Panel A reports difference-in-differences results on change in industry-adjusted abnormal ROA of the combined firms from the year before M\&A completion (t-1) to three years after M\&A completion ( $t+3$ ). The industry-adjusted ROA of the combined firm is estimated as the combined firm's ROA minus the median industry ROA from the same Fama-French 48 industry as the merged firms. We further calculate the difference between the combined firm's change in industry-adjusted ROA from the pre-M\&A year (t-1) to the post-M\&A completion year and that of the characteristic-matched peer firm over the same time period. The matched firm must remain public within the five-year window; not be involved in M\&A over the past three years; have market value within $90 \%$ to $110 \%$ of that of the combined firm; and have the closest ROA to that of the combined firm in the pre-M\&A year. P-values from the t-test/Wilcoxon Signed-rank test are reported in parentheses. Panel B presents results from regressions of post-M\&A change in industry-adjusted ROA on CEO compensation duration and portfolio duration. The dependent variable is change in industry-adjusted abnormal ROA of the combined firm from three years after M\&A completion $(t+3)$ to the pre-M\&A completion year ( $t-1)$. Columns (1) and (2) of Panel B present results from baseline OLS regressions. Columns (3) and (4) of Panel B present second-stage results from the Heckman selection model. All firm- and CEO-level explanatory variables are measured at the end of the fiscal year before M\&A announcement. See detailed variable definitions in Appendix A. All regressions include year and industry fixed effects based on Fama-French 48 classification. Heteroscedasticity-robust standard errors clustered by firms are reported in parentheses. *,**, and *** indicate significance at the $10 \%, 5 \%$, and $1 \%$ levels, respectively.

\begin{tabular}{|c|c|c|c|c|c|c|c|c|c|}
\hline \multicolumn{10}{|c|}{ Panel A. Difference-in-differences results on post-M\&A long-run abnormal ROA } \\
\hline & \multirow{2}{*}{\multicolumn{3}{|c|}{ Full sample }} & \multirow{2}{*}{\multicolumn{2}{|c|}{ Long compensation duration }} & \multirow{2}{*}{\multicolumn{2}{|c|}{ Short compensation duration }} & \multirow{2}{*}{\multicolumn{2}{|c|}{$\begin{array}{l}\text { Diff-in-Diff } \\
\text { Long - Short }\end{array}$}} \\
\hline & & & & & & & & & \\
\hline & 1 & 2 & 3 & 4 & 5 & 6 & 7 & 8 & 9 \\
\hline & Obs & Mean & Median & Mean & Median & Mean & Median & Diff. in Mean & Diff. in Median \\
\hline \multicolumn{10}{|c|}{$\triangle$ Industry-adj. ROA Combined Firm - $\triangle$ Industry-adj. ROA Matched Firm } \\
\hline $\mathrm{t}=-1$ to $\mathrm{t}=1$ & 366 & $\begin{array}{c}-1.60 \% * * * \\
(0.00)\end{array}$ & $\begin{array}{c}-1.55 \% * * * \\
(0.00)\end{array}$ & $\begin{array}{c}-2.30 \% * * * \\
(0.00)\end{array}$ & $\begin{array}{c}-1.99 \% * * * \\
(0.00)\end{array}$ & $\begin{array}{c}-0.68 \% \\
(0.22)\end{array}$ & $\begin{array}{c}-1.07 \% * \\
(0.08)\end{array}$ & $\begin{array}{c}-1.62 \% * * \\
(0.04)\end{array}$ & $\begin{array}{c}-0.92 \% \\
(0.40)\end{array}$ \\
\hline$t=-1$ to $t=2$ & 304 & $\begin{array}{c}-1.91 \% * * * \\
(0.00)\end{array}$ & $\begin{array}{c}-1.41 \% * * * \\
(0.00)\end{array}$ & $\begin{array}{c}-4.01 \% * * * \\
(0.00)\end{array}$ & $\begin{array}{c}-2.90 \% * * * \\
(0.00)\end{array}$ & $\begin{array}{l}0.27 \% \\
(0.67)\end{array}$ & $\begin{array}{c}-0.27 \% \\
(0.97)\end{array}$ & $\begin{array}{c}-4.28 \% * * * \\
(0.00)\end{array}$ & $\begin{array}{c}-2.64 \% * * * \\
(0.00)\end{array}$ \\
\hline$t=-1$ to $t=3$ & 259 & $\begin{array}{c}-1.74 \% * * * \\
(0.00)\end{array}$ & $\begin{array}{c}-1.20 \% \text { ** } \\
(0.01)\end{array}$ & $\begin{array}{c}-3.99 \% * * * \\
(0.00)\end{array}$ & $\begin{array}{c}-2.40 \% * * * \\
(0.00)\end{array}$ & $\begin{array}{l}1.20 \% \\
(0.11)\end{array}$ & $\begin{array}{l}1.16 \% \\
(0.14)\end{array}$ & $\begin{array}{c}-5.19 \% * * * \\
(0.00)\end{array}$ & $\begin{array}{c}-3.56 \% * * * \\
(0.00)\end{array}$ \\
\hline
\end{tabular}




\begin{tabular}{|c|c|c|c|c|}
\hline \multicolumn{5}{|c|}{ Panel B. Multivariate regression on post-M\&A change in industry adj. ROA } \\
\hline & \multicolumn{2}{|c|}{ OLS } & \multicolumn{2}{|c|}{ Heckman } \\
\hline & 1 & 2 & 3 & 4 \\
\hline COMPENSATION_DURATION & $\begin{array}{c}-1.628^{* * *} \\
(0.496)\end{array}$ & & $\begin{array}{c}-1.395 * * * \\
(0.499)\end{array}$ & \\
\hline PORTFOLIO_DURATION & & $\begin{array}{c}-2.128 * * * \\
(0.764)\end{array}$ & & $\begin{array}{c}-1.804 * * \\
(0.773)\end{array}$ \\
\hline CEO_OVERCONFIDENCE & $\begin{array}{c}-0.402 \\
(1.020)\end{array}$ & $\begin{array}{l}-1.370 \\
(1.046)\end{array}$ & $\begin{array}{l}-0.020 \\
(0.995)\end{array}$ & $\begin{array}{l}-0.795 \\
(1.036)\end{array}$ \\
\hline Log(TOTAL_ASSETS) & $\begin{array}{l}-0.007 \\
(0.373)\end{array}$ & $\begin{array}{l}-0.114 \\
(0.366)\end{array}$ & $\begin{array}{c}0.098 \\
(0.373)\end{array}$ & $\begin{array}{c}0.054 \\
(0.373)\end{array}$ \\
\hline PRIOR_YEAR_RETURN & $\begin{array}{c}0.346 \\
(0.901)\end{array}$ & $\begin{array}{c}0.311 \\
(0.906)\end{array}$ & $\begin{array}{c}0.970 \\
(0.956)\end{array}$ & $\begin{array}{c}1.038 \\
(0.976)\end{array}$ \\
\hline SALE_GROWTH & $\begin{array}{c}-5.862 * * * \\
(2.039)\end{array}$ & $\begin{array}{c}-6.282 * * * * \\
(2.177)\end{array}$ & $\begin{array}{c}-4.906^{* *} \\
(2.163)\end{array}$ & $\begin{array}{c}-4.946 * * \\
(2.276)\end{array}$ \\
\hline LONG-TERM_ASSETS & $\begin{array}{l}-0.898 \\
(2.265)\end{array}$ & $\begin{array}{c}0.273 \\
(2.332)\end{array}$ & $\begin{array}{l}-0.674 \\
(2.313)\end{array}$ & $\begin{array}{c}0.576 \\
(2.386)\end{array}$ \\
\hline CASH_FLOW & $\begin{array}{c}-9.053 * * * \\
(3.121)\end{array}$ & $\begin{array}{c}-9.484 * * * \\
(3.111)\end{array}$ & $\begin{array}{c}-7.314 * * * \\
(2.801)\end{array}$ & $\begin{array}{c}-7.810 * * * \\
(2.818)\end{array}$ \\
\hline STOCK_VOLATILITY & $\begin{array}{c}4.588 \\
(3.265)\end{array}$ & $\begin{array}{c}4.955 \\
(3.307)\end{array}$ & $\begin{array}{c}3.525 \\
(3.241)\end{array}$ & $\begin{array}{c}3.909 \\
(3.274)\end{array}$ \\
\hline RELATIVE_DEAL_SIZE & $\begin{array}{c}0.788 \\
(1.541)\end{array}$ & $\begin{array}{c}1.104 \\
(1.561)\end{array}$ & $\begin{array}{l}-0.178 \\
(1.471)\end{array}$ & $\begin{array}{c}0.145 \\
(1.477)\end{array}$ \\
\hline ALL_CASH & $\begin{array}{l}1.196 \\
(1.103)\end{array}$ & $\begin{array}{l}1.124 \\
(1.097)\end{array}$ & $\begin{array}{c}1.190 \\
(1.120)\end{array}$ & $\begin{array}{l}1.167 \\
(1.113)\end{array}$ \\
\hline HOSTILE & $\begin{array}{c}0.383 \\
(3.787)\end{array}$ & $\begin{array}{c}0.003 \\
(3.771)\end{array}$ & $\begin{array}{c}0.536 \\
(3.658)\end{array}$ & $\begin{array}{c}0.384 \\
(3.747)\end{array}$ \\
\hline TENDER & $\begin{array}{l}-0.705 \\
(1.191)\end{array}$ & $\begin{array}{l}-0.250 \\
(1.204)\end{array}$ & $\begin{array}{l}-0.338 \\
(1.174)\end{array}$ & $\begin{array}{c}0.096 \\
(1.193)\end{array}$ \\
\hline DIVERSIFIED_M\&A & $\begin{array}{c}1.390 \\
(0.882)\end{array}$ & $\begin{array}{c}1.251 \\
(0.890)\end{array}$ & $\begin{array}{c}1.221 \\
(0.855)\end{array}$ & $\begin{array}{c}1.102 \\
(0.855)\end{array}$ \\
\hline HERFINDAHL_INDEX & $\begin{array}{c}3.790 \\
(2.935)\end{array}$ & $\begin{array}{c}3.013 \\
(2.928)\end{array}$ & $\begin{array}{c}2.427 \\
(2.720)\end{array}$ & $\begin{array}{c}1.565 \\
(2.691)\end{array}$ \\
\hline INVERSE_MILLS_RATIO & & & $\begin{array}{l}4.122 \\
(2.535)\end{array}$ & $\begin{array}{l}4.951^{*} \\
(2.709)\end{array}$ \\
\hline Constant & $\begin{array}{l}-0.896 \\
(4.168)\end{array}$ & $\begin{array}{l}-1.485 \\
(4.289)\end{array}$ & $\begin{array}{l}-9.328 \\
(7.304)\end{array}$ & $\begin{array}{l}-11.977 \\
(7.878)\end{array}$ \\
\hline Year FE & Yes & Yes & Yes & Yes \\
\hline$R^{2}$ & 0.275 & 0.263 & 0.269 & 0.261 \\
\hline Observations & 352 & 352 & 348 & 348 \\
\hline
\end{tabular}


Table 6. CEO Compensation Duration and Post-M\&A Long-Run Abnormal Stock Performance

Panel A reports post-M\&A buy-and-hold abnormal returns (BHARs) of acquiring firms in the full sample and within above- and below- median CEO compensation duration subgroups. The groups are sorted based on acquirer CEO compensation duration in the fiscal year prior to the M\&A announcement. BHARs are measured as the difference of buy-and-hold returns between acquiring firms and their characteristic-matched firms. The matched firm must not be involved in M\&A over the past three years; must have a market value within $70 \%$ to $130 \%$ of the acquirer's market value measured 11 days prior to M\&A announcement date; and must have the closest market-to-book value to that of the acquirer at the end of the pre-M\&A fiscal year. We estimate BHARs over 12-, 24-, and 36-month holding periods after M\&A announcements. P-values from t-test/Wilcoxon Signed-rank test are reported in parentheses. Panel B presents results from regressions of post-M\&A long run BHARs on CEO compensation duration and portfolio duration. Columns (1) and (2) of Panel B present OLS regression results of 24-month post-M\&A BHARs, and Columns (5) and (6) of Panel B present OLS regression results of 36-month BHARs. Columns (3), (4), (7), and (8) of Panel B report the second-stage results from the Heckman selection model for 24- and 36-month post-M\&A BHARs, respectively. See detailed variable definitions in Appendix A. All regressions include year and industry fixed effects based on Fama-French 48 classification. Heteroscedasticity-robust standard errors clustered by firms are reported in parentheses. $*$, **, and *** indicate significance at the $10 \%, 5 \%$, and $1 \%$ levels, respectively.

\begin{tabular}{|c|c|c|c|c|c|c|c|c|c|}
\hline \multicolumn{10}{|c|}{ Panel A. Univariate analysis on post-M\&A long-run BHARs } \\
\hline & \multicolumn{3}{|c|}{ Full Sample } & \multicolumn{2}{|c|}{ Long Compensation Duration } & \multicolumn{2}{|c|}{ Short Compensation Duration } & \multicolumn{2}{|c|}{ Long - Short } \\
\hline & 1 & 2 & 3 & 4 & 5 & 6 & 7 & 8 & 9 \\
\hline & Obs. & Mean & Median & Mean & Median & Mean & Median & Diff. in Mean & Diff. in Median \\
\hline \multirow[t]{2}{*}[0,12]{} & 986 & $-1.97 \%$ & $-1.28 \%$ & $-4.44 \% * *$ & $-4.01 \% * *$ & $0.44 \%$ & $1.70 \%$ & $-4.88 \% *$ & $-5.71 \% *$ \\
\hline & & $(0.16)$ & $(0.41)$ & $(0.02)$ & $(0.05)$ & $(0.82)$ & $(0.40)$ & $(0.08)$ & $(0.06)$ \\
\hline \multirow[t]{2}{*}[0,24]{} & 853 & $-4.39 \% * *$ & $-1.75 \% * *$ & $-11.18 \% * * *$ & $-4.97 \% * * *$ & $2.61 \%$ & $0.68 \%$ & $-13.79 \% * *$ & $-5.65 \% *$ \\
\hline & & $(0.02)$ & $(0.04)$ & $(0.00)$ & $(0.00)$ & $(0.36)$ & $(0.63)$ & $(0.00)$ & $(0.06)$ \\
\hline \multirow[t]{2}{*}[0,36]{} & 759 & $-10.34 \% * * *$ & $-8.00 \% * * *$ & $-18.12 \% * * *$ & $-14.57 \% * * *$ & $-2.35 \%$ & $-3.82 \%$ & $-15.77 \% * * *$ & $-10.75 \% * *$ \\
\hline & & $(0.00)$ & $(0.00)$ & $(0.00)$ & $(0.00)$ & $(0.52)$ & $(0.30)$ & $(0.00)$ & $(0.01)$ \\
\hline
\end{tabular}




\begin{tabular}{|c|c|c|c|c|c|c|c|c|}
\hline \multicolumn{9}{|c|}{ Panel B Multivariate regression on post-M\&A long-run BHARs } \\
\hline & \multicolumn{4}{|c|}{ 24-month BHARs } & \multicolumn{4}{|c|}{ 36-month BHARs } \\
\hline & \multicolumn{2}{|c|}{ OLS } & \multicolumn{2}{|c|}{ Heckman } & \multicolumn{2}{|c|}{ OLS } & \multicolumn{2}{|c|}{ Heckman } \\
\hline & 1 & 2 & 3 & 4 & 5 & 6 & 7 & 8 \\
\hline COMPENSATION_DURATION & $\begin{array}{c}-5.921 * * \\
(2.495)\end{array}$ & & $\begin{array}{c}-6.753 * * * \\
(2.504)\end{array}$ & & $\begin{array}{c}-5.939 * \\
(3.178)\end{array}$ & & $\begin{array}{c}-6.950 * * \\
(3.269)\end{array}$ & \\
\hline PORTFOLIO_DURATION & & $\begin{array}{c}-8.960 * * \\
(4.019)\end{array}$ & & $\begin{array}{c}-9.654 * * \\
(4.091)\end{array}$ & & $\begin{array}{l}-9.068 \\
(5.892)\end{array}$ & & $\begin{array}{l}-9.491 \\
(6.056)\end{array}$ \\
\hline CEO_OVERCONFIDENCE & $\begin{array}{l}-2.800 \\
(4.656)\end{array}$ & $\begin{array}{l}-6.276 \\
(4.867)\end{array}$ & $\begin{array}{l}-4.234 \\
(4.723)\end{array}$ & $\begin{array}{l}-7.825 \\
(4.967)\end{array}$ & $\begin{array}{l}-7.163 \\
(6.442)\end{array}$ & $\begin{array}{l}-10.781 \\
(6.633)\end{array}$ & $\begin{array}{l}-9.199 \\
(6.508)\end{array}$ & $\begin{array}{c}-12.834 * \\
(6.735)\end{array}$ \\
\hline $\log ($ TOTAL_ASSETS) & $\begin{array}{c}1.892 \\
(1.777)\end{array}$ & $\begin{array}{c}1.365 \\
(1.745)\end{array}$ & $\begin{array}{c}0.732 \\
(1.960)\end{array}$ & $\begin{array}{c}0.195 \\
(1.947)\end{array}$ & $\begin{array}{l}-0.063 \\
(2.624)\end{array}$ & $\begin{array}{l}-0.444 \\
(2.561)\end{array}$ & $\begin{array}{l}-1.349 \\
(2.817)\end{array}$ & $\begin{array}{l}-1.750 \\
(2.790)\end{array}$ \\
\hline PRIOR_YEAR_RETURN & $\begin{array}{l}-3.644 \\
(3.636)\end{array}$ & $\begin{array}{l}-3.293 \\
(3.674)\end{array}$ & $\begin{array}{l}-4.870 \\
(3.735)\end{array}$ & $\begin{array}{l}-4.434 \\
(3.803)\end{array}$ & $\begin{array}{l}-5.038 \\
(4.433)\end{array}$ & $\begin{array}{l}-4.524 \\
(4.514)\end{array}$ & $\begin{array}{l}-6.378 \\
(4.570)\end{array}$ & $\begin{array}{l}-5.760 \\
(4.654)\end{array}$ \\
\hline ROA & $\begin{array}{c}12.375 \\
(23.387)\end{array}$ & $\begin{array}{c}14.482 \\
(23.584)\end{array}$ & $\begin{array}{c}4.218 \\
(24.875)\end{array}$ & $\begin{array}{c}8.231 \\
(25.076)\end{array}$ & $\begin{array}{l}-13.253 \\
(29.719)\end{array}$ & $\begin{array}{l}-11.414 \\
(29.817)\end{array}$ & $\begin{array}{l}-27.594 \\
(32.295)\end{array}$ & $\begin{array}{l}-24.015 \\
(32.565)\end{array}$ \\
\hline ROE & $\begin{array}{c}8.705 \\
(13.907)\end{array}$ & $\begin{array}{c}6.471 \\
(14.458)\end{array}$ & $\begin{array}{c}8.744 \\
(13.837)\end{array}$ & $\begin{array}{c}6.202 \\
(14.379)\end{array}$ & $\begin{array}{l}24.973 * \\
(15.103)\end{array}$ & $\begin{array}{c}22.361 \\
(15.226)\end{array}$ & $\begin{array}{l}25.738^{*} \\
(15.044)\end{array}$ & $\begin{array}{c}22.764 \\
(15.143)\end{array}$ \\
\hline SALE_GROWTH & $\begin{array}{c}0.660 \\
(8.023)\end{array}$ & $\begin{array}{l}-0.687 \\
(8.093)\end{array}$ & $\begin{array}{l}-5.097 \\
(8.545)\end{array}$ & $\begin{array}{l}-6.071 \\
(8.611)\end{array}$ & $\begin{array}{l}-12.933 \\
(10.342)\end{array}$ & $\begin{array}{l}-14.296 \\
(10.572)\end{array}$ & $\begin{array}{c}-19.006^{*} \\
(11.421)\end{array}$ & $\begin{array}{c}-19.802 * \\
(11.623)\end{array}$ \\
\hline STOCK_VOLATILITY & $\begin{array}{l}-21.299 \\
(13.682)\end{array}$ & $\begin{array}{l}-20.265 \\
(13.651)\end{array}$ & $\begin{array}{l}-20.719 \\
(13.693)\end{array}$ & $\begin{array}{c}-19.874 \\
(13.667)\end{array}$ & $\begin{array}{l}-17.343 \\
(19.751)\end{array}$ & $\begin{array}{c}-15.986 \\
(19.789)\end{array}$ & $\begin{array}{l}-16.846 \\
(20.020)\end{array}$ & $\begin{array}{l}-15.927 \\
(20.048)\end{array}$ \\
\hline CASH_FLOW & $\begin{array}{l}13.237 \\
(8.341)\end{array}$ & $\begin{array}{l}12.844 \\
(8.463)\end{array}$ & $\begin{array}{l}15.244^{*} \\
(9.033)\end{array}$ & $\begin{array}{l}14.031 \\
(9.230)\end{array}$ & $\begin{array}{c}21.000 * * \\
(9.114)\end{array}$ & $\begin{array}{c}21.227 * * \\
(9.306)\end{array}$ & $\begin{array}{c}25.516^{* *} \\
(10.268)\end{array}$ & $\begin{array}{r}24.994 * * \\
(10.559)\end{array}$ \\
\hline FIRM_AGE & $\begin{array}{l}-2.298 \\
(3.445)\end{array}$ & $\begin{array}{l}-1.425 \\
(3.456)\end{array}$ & $\begin{array}{l}-0.514 \\
(3.623)\end{array}$ & $\begin{array}{c}0.225 \\
(3.630)\end{array}$ & $\begin{array}{l}-5.269 \\
(5.488)\end{array}$ & $\begin{array}{l}-4.430 \\
(5.460)\end{array}$ & $\begin{array}{l}-3.102 \\
(5.793)\end{array}$ & $\begin{array}{l}-2.477 \\
(5.788)\end{array}$ \\
\hline CEO_SHAREHOLDINGS & $\begin{array}{l}-0.127 \\
(0.545)\end{array}$ & $\begin{array}{l}-0.285 \\
(0.535)\end{array}$ & $\begin{array}{l}-0.111 \\
(0.547)\end{array}$ & $\begin{array}{l}-0.246 \\
(0.536)\end{array}$ & $\begin{array}{l}-0.215 \\
(0.622)\end{array}$ & $\begin{array}{l}-0.416 \\
(0.637)\end{array}$ & $\begin{array}{l}-0.218 \\
(0.618)\end{array}$ & $\begin{array}{l}-0.375 \\
(0.635)\end{array}$ \\
\hline ANNUAL_COMPENSATION & $\begin{array}{c}0.506 \\
(0.419)\end{array}$ & $\begin{array}{c}0.368 \\
(0.427)\end{array}$ & $\begin{array}{c}0.546 \\
(0.483)\end{array}$ & $\begin{array}{c}0.348 \\
(0.486)\end{array}$ & $\begin{array}{l}1.250^{*} \\
(0.748)\end{array}$ & $\begin{array}{c}1.185 \\
(0.751)\end{array}$ & $\begin{array}{c}1.463^{*} \\
(0.814)\end{array}$ & $\begin{array}{c}1.340 \\
(0.824)\end{array}$ \\
\hline RELATIVE_DEAL_SIZE & $\begin{array}{c}-10.623 \\
(9.848)\end{array}$ & $\begin{array}{l}-7.754 \\
(9.693)\end{array}$ & $\begin{array}{l}-9.676 \\
(9.906)\end{array}$ & $\begin{array}{l}-6.803 \\
(9.770)\end{array}$ & $\begin{array}{c}6.400 \\
(15.730)\end{array}$ & $\begin{array}{c}8.684 \\
(15.832)\end{array}$ & $\begin{array}{c}7.364 \\
(15.728)\end{array}$ & $\begin{array}{c}9.480 \\
(15.839)\end{array}$ \\
\hline HOSTILE & $\begin{array}{c}-9.561 \\
(16.445)\end{array}$ & $\begin{array}{c}-8.729 \\
(15.280)\end{array}$ & $\begin{array}{l}-10.965 \\
(16.520)\end{array}$ & $\begin{array}{l}-10.207 \\
(15.270)\end{array}$ & $\begin{array}{l}-19.198 \\
(19.710)\end{array}$ & $\begin{array}{l}-17.705 \\
(19.351)\end{array}$ & $\begin{array}{l}-20.744 \\
(20.369)\end{array}$ & $\begin{array}{c}-19.405 \\
(19.914)\end{array}$ \\
\hline TENDER & $\begin{array}{l}-1.129 \\
(5.648)\end{array}$ & $\begin{array}{c}-0.094 \\
(5.696)\end{array}$ & $\begin{array}{l}-0.977 \\
(5.628)\end{array}$ & $\begin{array}{c}0.024 \\
(5.675)\end{array}$ & $\begin{array}{l}-4.947 \\
(8.164)\end{array}$ & $\begin{array}{l}-3.801 \\
(8.085)\end{array}$ & $\begin{array}{l}-4.579 \\
(8.204)\end{array}$ & $\begin{array}{l}-3.534 \\
(8.121)\end{array}$ \\
\hline ALL_CASH & $\begin{array}{c}0.792 \\
(4.499)\end{array}$ & $\begin{array}{c}1.267 \\
(4.506)\end{array}$ & $\begin{array}{c}0.690 \\
(4.542)\end{array}$ & $\begin{array}{c}1.204 \\
(4.556)\end{array}$ & $\begin{array}{c}4.949 \\
(6.775) \\
\end{array}$ & $\begin{array}{c}5.072 \\
(6.823)\end{array}$ & $\begin{array}{c}4.407 \\
(6.768)\end{array}$ & $\begin{array}{c}4.598 \\
(6.828)\end{array}$ \\
\hline
\end{tabular}




\begin{tabular}{|c|c|c|c|c|c|c|c|c|}
\hline \multirow{2}{*}{ PUBLIC_TARGET } & 4.390 & 3491 & 4.001 & 3.178 & -1789 & -2232 & -2130 & $-2,489$ \\
\hline & $(4.884)$ & $(4.880)$ & $(4.907)$ & $(4.917)$ & $(6.587)$ & $(6.661)$ & $(6.589)$ & $(6.678)$ \\
\hline \multirow[t]{2}{*}{ DIVERSIFIED_M\&A } & -6.323 & -6.242 & -6.517 & -6.314 & -6.303 & -5.989 & -6.921 & -6.521 \\
\hline & $(4.635)$ & $(4.639)$ & $(4.655)$ & $(4.660)$ & $(6.415)$ & $(6.399)$ & $(6.461)$ & $(6.447)$ \\
\hline \multirow[t]{2}{*}{ HERFINDAHL_INDEX } & -12.471 & -15.229 & -8.562 & -11.716 & -7.870 & -10.931 & -3.705 & -7.171 \\
\hline & $(12.441)$ & (12.619) & $(12.545)$ & $(12.761)$ & $(18.703)$ & $(18.676)$ & $(19.151)$ & $(19.149)$ \\
\hline \multirow[t]{2}{*}{ INVERSE_MILLS_RATIO } & & & -20.259 & -18.091 & & & -23.923 & -21.343 \\
\hline & & & $(12.411)$ & $(12.511)$ & & & $(18.408)$ & $(18.357)$ \\
\hline \multirow[t]{2}{*}{ Constant } & 7.109 & 6.947 & 51.429 & 46.832 & 38.507 & 36.661 & $90.317^{*}$ & $83.285^{*}$ \\
\hline & $(18.533)$ & $(18.603)$ & $(33.365)$ & (33.907) & $(28.374)$ & $(28.403)$ & $(46.972)$ & $(47.257)$ \\
\hline Ind. and Yr. FE & Yes & Yes & Yes & Yes & Yes & Yes & Yes & Yes \\
\hline$R^{2}$ & 0.108 & 0.107 & 0.111 & 0.109 & 0.094 & 0.093 & 0.098 & 0.097 \\
\hline Observations & 784 & 784 & 779 & 779 & 725 & 725 & 720 & 720 \\
\hline
\end{tabular}


Table 7. Robustness Tests: 2SLS IV Regressions

This table presents robustness tests on the relation between M\&A performance and CEO compensation duration using 2SLS IV regression model. The instrument variable is median CEO compensation duration from non-industry-clustered peer firms within the same MSA code (MSA_PEER_COMPENSATION_DURATION). Columns (1), (3), and (5) report the first regression stage results. Columns (2), (4), and (6) report second-stage results on acquirer cumulative abnormal returns over a three-day event window around M\&A announcements, change in industry-adjusted abnormal ROA of the combined firm from three years after M\&A completion $(t+3)$ to the year before M\&A completion (t-1), and 24-month post-M\&A buy-and-hold abnormal returns (BHARs), respectively. To preserve space, we present only coefficients on the instrument variable in the first stage and coefficients on the predicted CEO pay duration in the second stage. The regression control variables are the same as in Panel B of Tables 4, 5, and 6. See detailed variable definitions in Appendix A. All regressions include year and industry fixed effects based on Fama-French 48 classification. Heteroscedasticityrobust standard errors clustered by firms are reported in parentheses. *,**, and *** indicate significance at the $10 \%, 5 \%$, and $1 \%$ levels, respectively.

\begin{tabular}{|c|c|c|c|c|c|c|}
\hline & $\begin{array}{c}1^{\text {st }} \text { Stage } \\
\text { Compensatio } \\
\text { n duration }\end{array}$ & $\begin{array}{c}2^{\text {nd }} \text { Stage } \\
\text { 3-day CAR around } \\
\text { M\&A ann. date }\end{array}$ & $\begin{array}{c}1^{\text {st }} \text { Stage } \\
\text { Compensatio } \\
\text { n duration }\end{array}$ & $\begin{array}{c}2^{\text {nd }} \text { Stage } \\
\Delta \text { in Industry adj. } \\
\text { ROA }\end{array}$ & $\begin{array}{c}1^{\text {st }} \text { Stage } \\
\text { Compensatio } \\
\text { n duration }\end{array}$ & $\begin{array}{c}2^{\text {nd }} \text { Stage } \\
\text { 24-month post- } \\
\text { M\&A BHARs }\end{array}$ \\
\hline & 1 & 2 & 3 & 4 & 5 & 6 \\
\hline MSA_PEER_COMPENSATION_DURATION & $\begin{array}{c}0.468 * * * \\
(0.088)\end{array}$ & & $\begin{array}{c}0.900 * * * \\
(0.119)\end{array}$ & & $\begin{array}{c}0.544 * * * \\
(0.092)\end{array}$ & \\
\hline PREDICTED_COMPENSATION_DURATION & & $\begin{array}{c}-2.947 * * \\
(1.401)\end{array}$ & & $\begin{array}{l}-2.201 * \\
(1.280)\end{array}$ & & $\begin{array}{c}-29.048 * * \\
(12.379)\end{array}$ \\
\hline Control variables & Yes & Yes & Yes & Yes & Yes & Yes \\
\hline Ind. and Yr. FE & Yes & Yes & Yes & Yes & Yes & Yes \\
\hline Observations & 1,035 & 1,035 & 328 & 328 & 764 & 764 \\
\hline First-Stage F-statisic & $28.44 * * *$ & & $56.93 * * *$ & & $35.07 * * *$ & \\
\hline Kleibergen-Paap rk LM statistic & & $18.97 * * *$ & & $24.68 * * *$ & & $24.82 * * *$ \\
\hline Cragg-Donald Wald F statistic & & 39.46 & & 47.43 & & 37.01 \\
\hline
\end{tabular}


Table 8. Robustness Tests: Propensity Score Matched Sample

This table presents robustness tests on the relation between acquirer CEO compensation duration and M\&A performance using a propensity score matched sample. Panel A compares firm characteristics of acquirers with abovemedian CEO compensation duration (treated) and matched firms (control). Panel B reports the M\&A performance regression results using the propensity score matched sample. Columns (1) to (3) report results on the acquirers' threeday CARs around M\&A announcement dates, change in industry-adjusted ROA of the combined firm from three years after M\&A completion $(t+3)$ to the pre-M\&A completion year ( $t-1)$, and 24-month post-M\&A buy-and-hold abnormal returns (BHARs), respectively. To preserve space, we only present coefficients on CEO compensation duration. The regression control variables are the same as in Panel B of Tables 4, 5, and 6. See detailed variable definitions in Appendix A. All regressions include year and industry fixed effects based on Fama-French 48 classification. Heteroscedasticity-robust standard errors clustered by firms are reported in parentheses. *, **, and *** indicate significance at the $10 \%, 5 \%$, and $1 \%$ levels, respectively.

\begin{tabular}{|c|c|c|c|c|c|}
\hline \multicolumn{6}{|c|}{ Panel A. Firm characteristics of treated and matched firms } \\
\hline & $\begin{array}{c}\text { Treated } \\
\text { firms obs. }\end{array}$ & $\begin{array}{l}\text { Mean. } \\
\text { Treatment }\end{array}$ & $\begin{array}{l}\text { Mean. } \\
\text { Control }\end{array}$ & $\begin{array}{c}\text { Difference } \\
\text { Treatment - } \\
\text { Control }\end{array}$ & t-statistic \\
\hline $\log ($ TOTAL_ASSETS) & 394 & 8.382 & 8.363 & 0.019 & 0.161 \\
\hline LONG-TERM_ASSETS & 394 & 0.385 & 0.376 & 0.009 & 0.562 \\
\hline R\&D expense & 394 & 0.036 & 0.040 & -0.004 & -1.059 \\
\hline FIRM_Q & 394 & 2.770 & 3.009 & -0.239 & -0.762 \\
\hline CASH_FLOW & 394 & 0.011 & 0.003 & 0.008 & 0.232 \\
\hline STOCK_VOLATILITY & 394 & 0.440 & 0.454 & -0.014 & -0.886 \\
\hline SALES_VOLATILITY & 394 & 0.414 & 0.440 & -0.026 & -0.304 \\
\hline CASH_VOLATILITY & 394 & 0.229 & 0.239 & -0.010 & -0.255 \\
\hline LEVERAGE & 394 & 0.210 & 0.200 & 0.010 & 0.906 \\
\hline STOCK_SPREAD & 394 & 0.140 & 0.139 & 0.001 & 0.099 \\
\hline PRIOR_YEAR_RETURN & 394 & 0.357 & 0.391 & -0.034 & -0.491 \\
\hline \multicolumn{6}{|c|}{ Panel B. Multivariate regression results with PSM matched samples } \\
\hline & \multicolumn{2}{|c|}{$\begin{array}{c}\text { Three-Day CAR } \\
\text { around M\&As }\end{array}$} & \multicolumn{2}{|c|}{$\begin{array}{c}\Delta \text { in Industry adj. } \\
\text { ROA }\end{array}$} & $\begin{array}{l}\text { 24-month post- } \\
\text { M\&A BHARs }\end{array}$ \\
\hline \multirow[b]{2}{*}{ COMPENSATION_DURATION } & \multicolumn{2}{|l|}{1} & \multicolumn{2}{|c|}{2} & 3 \\
\hline & \multicolumn{2}{|c|}{$-0.975^{* * *}$} & \multicolumn{2}{|c|}{$-1.673^{*}$} & $\begin{array}{c}-6.049 * * \\
(2.955)\end{array}$ \\
\hline Control variables & \multicolumn{2}{|c|}{ Yes } & \multicolumn{2}{|c|}{ Yes } & Yes \\
\hline Ind. and Yr. FE & \multicolumn{2}{|c|}{ Yes } & \multicolumn{2}{|c|}{ Yes } & Yes \\
\hline$R^{2}$ & \multicolumn{2}{|c|}{0.167} & \multicolumn{2}{|c|}{0.416} & 0.201 \\
\hline Observations & \multicolumn{2}{|c|}{668} & \multicolumn{2}{|c|}{101} & 553 \\
\hline
\end{tabular}


Table 9. Corporate Governance, CEO Compensation Duration, and M\&A Performance

This table presents OLS regression results of M\&A performance on acquirer CEO pay duration and corporate governance. To preserve space, we only present coefficients on acquirer CEO compensation duration, governance characteristics, and interaction terms. The regression control variables are the same as in Tables 5, 7, and 9. See detailed variable definitions in Appendix A. All regressions include year and industry fixed effect based on FamaFrench 48 classification. Heteroscedasticity-robust standard errors clustered by firms are reported in parentheses. *, $* *$, and $* * *$ indicate significance at the $10 \%, 5 \%$, and $1 \%$ levels, respectively.

\begin{tabular}{|c|c|c|c|}
\hline & $\begin{array}{c}\text { Three-Day CAR } \\
\text { around M\&As }\end{array}$ & $\begin{array}{c}\Delta \text { in Industry adj. } \\
\text { ROA }\end{array}$ & $\begin{array}{l}\text { 24-month post- } \\
\text { M\&A BHARs }\end{array}$ \\
\hline \multirow[t]{2}{*}{ COMPENSATION_DURATION } & $-0.917 *$ & $-2.903 * * *$ & $-16.200 * * *$ \\
\hline & $(0.528)$ & (1.114) & (5.944) \\
\hline \multirow[t]{2}{*}{ CEO_TEUNURE } & -0.067 & $-0.338 * *$ & -0.602 \\
\hline & $(0.067)$ & $(0.168)$ & $(0.827)$ \\
\hline COMPENSATION_DURATION $\times$ & 0.049 & 0.090 & 0.156 \\
\hline CEO_TENURE & $(0.046)$ & $(0.090)$ & $(0.446)$ \\
\hline \multirow[t]{2}{*}{ CO-OPTED_BOARD } & 1.083 & 4.323 & -6.114 \\
\hline & (1.778) & $(2.812)$ & $(24.572)$ \\
\hline COMPENSATION_DURATION $\times$ & -0.151 & -0.426 & 15.184 \\
\hline CO-OPTED_BOARD & $(1.024)$ & $(1.547)$ & (11.307) \\
\hline \multirow[t]{2}{*}{ CEO_DUALITY } & -0.123 & -2.876 & -6.640 \\
\hline & $(1.135)$ & $(1.907)$ & $(12.760)$ \\
\hline COMPENSATION_DURATION $\times$ & 0.296 & 1.055 & -0.607 \\
\hline CEO_DUALITY & $(0.565)$ & $(0.982)$ & $(6.462)$ \\
\hline Control variables & Yes & Yes & Yes \\
\hline Ind. and Yr. FE & Yes & Yes & Yes \\
\hline$R^{2}$ & 0.170 & 0.270 & 0.219 \\
\hline Observations & 804 & 275 & 612 \\
\hline
\end{tabular}


Table 10. Time-Vesting vs. Performance-Vesting Compensation Duration

This table presents results from regressions of M\&A performance on acquirer CEO's time-vesting compensation duration and performance-vesting compensation duration. To preserve space, we only present coefficients on CEO TIME-VESTING_DURATION and PERFORMANCE-VESTING_DURATION. The regression control variables are the same as in Panel A of Tables 4, 5, and 6. See detailed variable definitions in Appendix A. Heteroscedasticityrobust standard errors clustered by firms are reported in parentheses. $*, * *$, and $* * *$ indicate significance at the $10 \%$, $5 \%$, and $1 \%$ levels, respectively.

\begin{tabular}{|c|c|c|c|}
\hline & $\begin{array}{c}\text { Three-day CAR } \\
\text { around M\&As }\end{array}$ & $\begin{array}{l}\Delta \text { in Industry } \\
\text { adj. ROA }\end{array}$ & $\begin{array}{c}\text { 24-month post-M\&A } \\
\text { BHARs }\end{array}$ \\
\hline & 1 & 2 & 3 \\
\hline TIME-VESTING_DURATION & $\begin{array}{l}-0.369^{*} \\
(0.215)\end{array}$ & $\begin{array}{c}-0.957 * * \\
(0.420)\end{array}$ & $\begin{array}{c}-3.395^{* *} \\
(1.717)\end{array}$ \\
\hline PERFORMANCE-VESTING_DURATION & $\begin{array}{c}0.023 \\
(0.146)\end{array}$ & $\begin{array}{l}-0.084 \\
(0.299)\end{array}$ & $\begin{array}{l}-0.195 \\
(1.521)\end{array}$ \\
\hline Control variables & Yes & Yes & Yes \\
\hline Ind. and Yr. FE & Yes & Yes & Yes \\
\hline$R^{2}$ & 0.118 & 0.222 & 0.107 \\
\hline Observations & 1,067 & 352 & 784 \\
\hline
\end{tabular}


Figure 1: Distribution of CEO Pay Component by Year

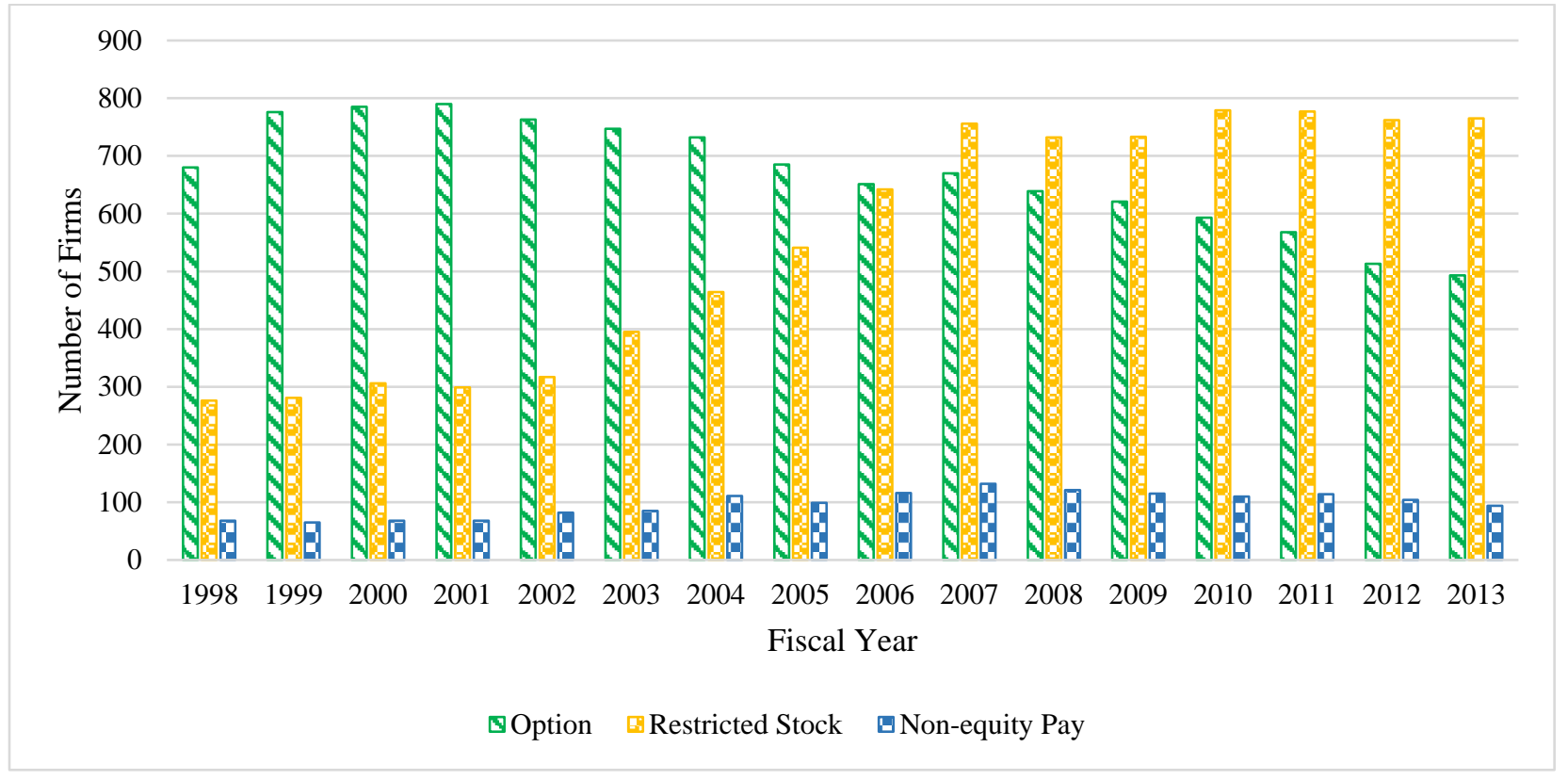

Figure 2. Distribution of Time-Vesting and Performance-Vesting Grants to CEOs by Year

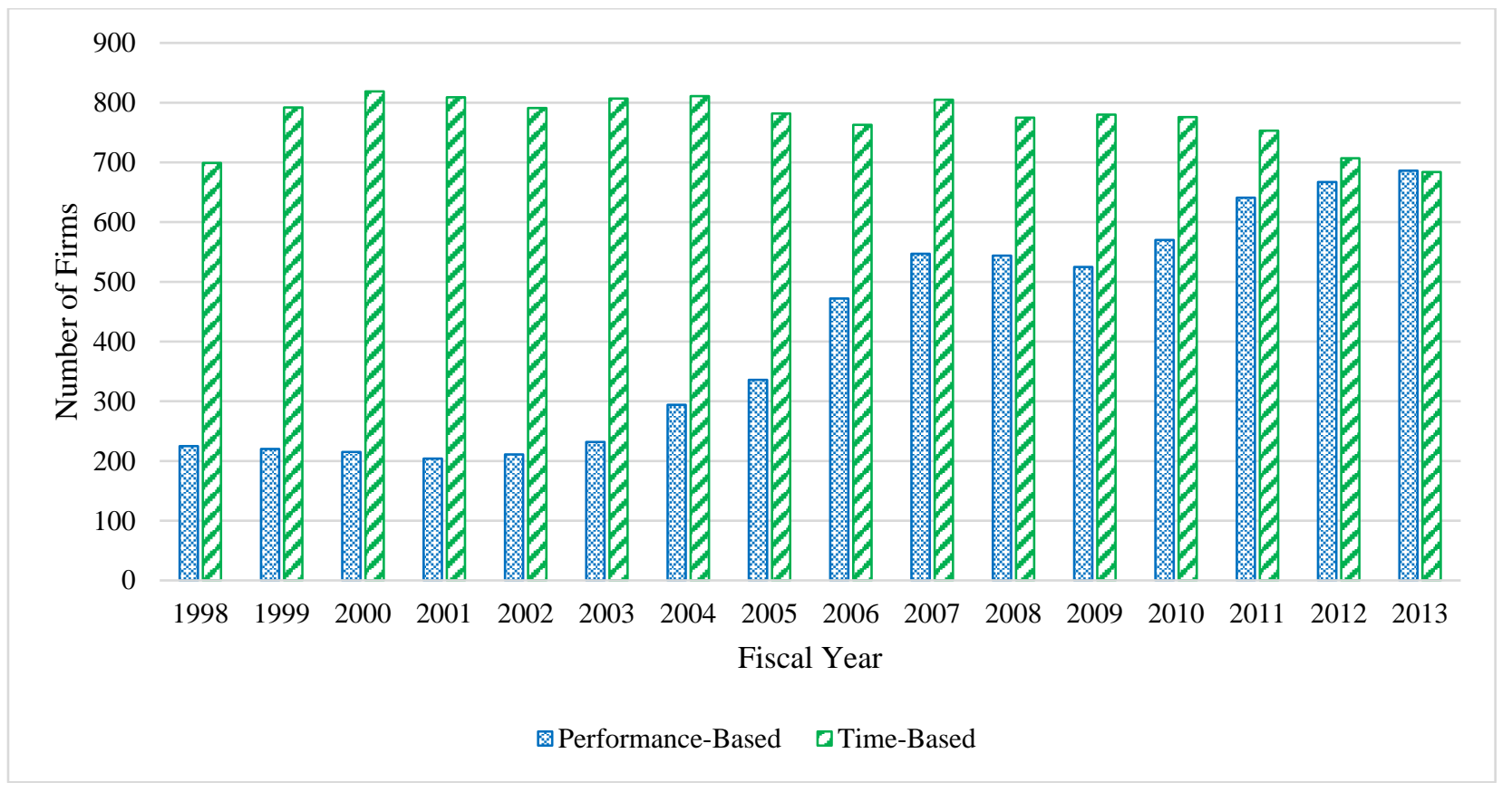


Appendix A. Variable Definition

\begin{tabular}{|c|c|c|}
\hline Variables & Definition & Data Source \\
\hline ALL_CASH & Taking value one if the M\&A transaction is paid with all cash & SDC \\
\hline $\begin{array}{l}\text { ANNUAL_- } \\
\text { COMPENSATION }\end{array}$ & $\begin{array}{l}\text { The ratio of CEO total pay (TDC1) on total book value of total assets at } \\
\text { the end of the fiscal year }\end{array}$ & $\begin{array}{l}\text { Execucomp, } \\
\text { Compustat }\end{array}$ \\
\hline BONUS ( $\$$ thousand) & The executive's reported annual bonus value & Execucomp \\
\hline CASH_FLOW & $\begin{array}{l}\text { The cash flow from operations to lagged total assets. The cash flow } \\
\text { from operations is the difference between EBIT and the change of net } \\
\text { working capital }\end{array}$ & Compustat \\
\hline CASH_VOLATILITY & $\begin{array}{l}\text { The standard deviation of the ratio of demeaned cash balance over } \\
\text { lagged book value of total assets over the previous five years }\end{array}$ & Compustat \\
\hline CEO_AGE (years) & The executives' ages in the given year & Execucomp \\
\hline CEO_DUALITY & $\begin{array}{l}\text { Indicator variable that equals } 1 \text { if a CEO is also the chairman of board } \\
\text { in the given year }\end{array}$ & RiskMetrics \\
\hline $\begin{array}{l}\mathrm{CEO}_{-} \\
\text {OVERCONFIDENCE }\end{array}$ & $\begin{array}{l}\text { Indicator variable that equals } 1 \text { if the CEO has options more than } 100 \% \\
\text { in-the-money in the fifth year during their sample tenure }\end{array}$ & Execucomp \\
\hline CEO_TENURE (years) & $\begin{array}{l}\text { Number of years served as CEO; if the firm is missing CEO tenure in a } \\
\text { year, we replace it with the median of the CEO tenure in the given year }\end{array}$ & Execucomp \\
\hline $\begin{array}{l}\text { CEO_- } \\
\text { SHAREHOLDINGS }(\%)\end{array}$ & The executives' share ownership as a \% of total shares outstanding & Execucomp \\
\hline $\begin{array}{l}\text { COMPENSATION_} \\
\text { DURATION (years) }\end{array}$ & $\begin{array}{l}\text { Executive compensation duration calculated using both equity and non- } \\
\text { equity grants during the year }\end{array}$ & $\begin{array}{l}\text { ISS Incentive } \\
\text { Lab }\end{array}$ \\
\hline CO-OPTED_BOARD & $\begin{array}{l}\text { The number of directors appointed after the CEO assumed office } \\
\text { divided by the board size }\end{array}$ & $\begin{array}{l}\text { Lalitha } \\
\text { Naveen's } \\
\text { website }\end{array}$ \\
\hline DEAL_SIZE & The value of acquisition reported in millions & SDC \\
\hline DIVERSIFIED_M\&A & $\begin{array}{l}\text { Taking value one if the acquirer and targets belong to the same four- } \\
\text { digit SIC industry categories }\end{array}$ & SDC \\
\hline FIRM_AGE & The number of years that firms are listed in Compustat & Compustat \\
\hline FIRM_Q & $\begin{array}{l}\text { The ratio of the market value of total assets over the book value of total } \\
\text { assets }\end{array}$ & Compustat \\
\hline HERFINDAHL INDEX & $\begin{array}{l}\text { The sum of the squared market share of each firm competing in each } \\
\text { Fama-French } 48 \text { industry. }\end{array}$ & Compustat \\
\hline HOSTILE & Taking value one if the M\&A transaction is hostile & SDC \\
\hline LEVERAGE & $\begin{array}{l}\text { The ratio of the sum of long-term (dltt) and short-term debt (dlc) to the } \\
\text { book value of total assets }\end{array}$ & Compustat \\
\hline LONG-TERM_ASSETS ' & The ratio of fixed assets (ppent) to the book value of total assets & Compustat \\
\hline $\begin{array}{l}\text { LONG-TERM_NON- } \\
\text { EQUITY_DURATION }\end{array}$ & $\begin{array}{l}\text { Executive compensation duration calculated only with non-equity based } \\
\text { plans during the year }\end{array}$ & $\begin{array}{l}\text { dISS Incentive } \\
\text { Lab }\end{array}$ \\
\hline LOG (TOTAL_ASSETS) & $\begin{array}{l}\text { The logarithm of the total book value of total assets at the end of the } \\
\text { fiscal year }\end{array}$ & Compustat \\
\hline $\begin{array}{l}\text { INTERIM_INDUSTRY } \\
\text { UNCERTAINTY }\end{array}$ & $\begin{array}{l}\text { The median of industry peer's pre-M\&A market beta. We calculate the } \\
\text { peer's beta using monthly stock return and monthly market portfolio } \\
\text { return from the fiscal year before the announcement date. }\end{array}$ & CRSP \\
\hline $\begin{array}{l}\text { MSA_COMP } \\
\text { DURATION (years) }\end{array}$ & $\begin{array}{l}\text { The median CEO pay duration of firms from the same MSA area } \\
\text { excluding firms with industry cluster defined in Almazan et al. (2010) }\end{array}$ & $\begin{array}{l}\text { ISS Incentive } \\
\text { Lab }\end{array}$ \\
\hline $\begin{array}{l}\text { OPTION_DURATION } \\
\text { (years) }\end{array}$ & $\begin{array}{l}\text { Executive compensation duration calculated only with option-based } \\
\text { plans during the year }\end{array}$ & $\begin{array}{l}\text { ISS Incentive } \\
\mathrm{Lab}\end{array}$ \\
\hline OPTIONS ( $\$$ thousand) & $\begin{array}{l}\text { The Black-Scholes value of the options granted to the executives } \\
\text { during the year, following Coles, Naveen, and Daniels (2006) }\end{array}$ & Execucomp \\
\hline
\end{tabular}




\begin{tabular}{|c|c|c|}
\hline $\begin{array}{l}\text { PERFORMANCE- } \\
\text { VESTING_DURATION }\end{array}$ & $\begin{array}{l}\text { Executive compensation duration calculated only with performance- } \\
\text { vesting plans during the year }\end{array}$ & $\begin{array}{l}\text { ISS Incentive } \\
\mathrm{Lab}\end{array}$ \\
\hline $\begin{array}{l}\text { PORTFOLIO_ } \\
\text { DURATION (years) }\end{array}$ & $\begin{array}{l}\text { Executive compensation duration calculated using vested and unvested } \\
\text { holdings in executive portfolio }\end{array}$ & $\begin{array}{l}\text { ISS Incentive } \\
\mathrm{Lab}\end{array}$ \\
\hline $\begin{array}{l}\text { PRIOR_YEAR_ } \\
\text { RETURNS }\end{array}$ & The cumulative buy and hold return in the fiscal year & CRSP \\
\hline PUBLIC_TARGET & Taking value one if the target is a public firm & $\mathrm{SDC}$ \\
\hline R\&D_EXPENSE & $\begin{array}{l}\text { Firm's R\&D expense to the book value of total assets. R\&D expense is } \\
\text { assumed to be zero if missing. }\end{array}$ & Compustat \\
\hline $\begin{array}{l}\text { RELATIVE_- } \\
\text { DEAL_SIZE }\end{array}$ & $\begin{array}{l}\text { The ratio of acquisition value over the market value of the acquirer at } \\
\text { the end of the fiscal year before the announcement date }\end{array}$ & $\mathrm{SDC}$ \\
\hline $\begin{array}{l}\text { RESTRICTED_STOCK } \\
\text { (\$ thousand) }\end{array}$ & The value of restricted stock granted to the executives during the year & Execucomp \\
\hline ROA & $\begin{array}{l}\text { The ratio of operating income before interest, depreciation, and tax } \\
\text { (oibdp) to the book value of asset }\end{array}$ & Compustat \\
\hline ROE & $\begin{array}{l}\text { The ratio of operating income before interest, depreciation, and tax } \\
\text { (oibdp) to the book value of equity }\end{array}$ & Compustat \\
\hline SALES_GROWTH & The firm's annual sale growth & Compustat \\
\hline SALES_VOLATILITY & $\begin{array}{l}\text { The standard deviation of the firms' annual sales growth over the } \\
\text { previous five years }\end{array}$ & Compustat \\
\hline SALARY ( $\$$ thousand $)$ & The executives' annual salaries & Execucomp \\
\hline $\begin{array}{l}\text { STOCK_DURATION } \\
\text { (years) }\end{array}$ & $\begin{array}{l}\text { Executive compensation duration calculated only with stock-based } \\
\text { plans during the year }\end{array}$ & $\begin{array}{l}\text { ISS Incentive } \\
\text { Lab }\end{array}$ \\
\hline STOCK_SPREAD $(\%)$ & The average daily stock bid-ask spread in the fiscal year & CRSP \\
\hline STOCK_VOLATILITY & $\begin{array}{l}\text { The stock return volatility calculated as annualized volatility of daily } \\
\text { stock returns during the previous year }\end{array}$ & Compustat \\
\hline TENDER & Taking value one if the transaction is a tender offer & $\mathrm{SDC}$ \\
\hline $\begin{array}{l}\text { TIME-VESTING_ } \\
\text { DURATION }\end{array}$ & $\begin{array}{l}\text { Executive compensation duration calculated only with time-vesting } \\
\text { plans during the year }\end{array}$ & $\begin{array}{l}\text { ISS Incentive } \\
\text { Lab }\end{array}$ \\
\hline $\begin{array}{l}\text { TOTAL_ASSETS } \\
\text { (\$ million) }\end{array}$ & The book value of total assets at the end of the fiscal year & Compustat \\
\hline
\end{tabular}

TOTAL_COMPENSATI The TDC1 reported in Execucomp as the sum of salary, bonus, other ON (\$ thousand) annual compensation, long-term incentive payouts, other cash payoutsm and total value of restricted stock option awards

TOTAL_SALES (\$ million) The total revenue at the end of the fiscal year

Execucomp BUY-ANDThe difference between buy-and-hold returns of the acquirers over 12-, HOLD_ABNORMAL_ 24-, or 36-month after M\&A completion and that of matched RETURNS (BHARs) benchmark firms over the same period. We follow Baber and Lyon (1997) to find a matched firm that has not been involved in any M\&A over the past 3 years, has market value within $70 \%-130 \%$ of the acquirer's market value, and has the closest market-to-book ratio to that of the acquirer at the fiscal year end prior to M\&A announcement date. We require 12-month returns to calculate 12-month BHARs, and no less than 20-month returns calculate 24-month and 36-month BHARs. 